41

London, $14^{\text {th }}$ Feb. 1848

My dear Thomson

I then may congratulate you at last - on coming to your Kingdom - but write you also for another purpose.

When I last saw you you expressed a wish to join the Royal Society - and on mentioning your name to some influential members, they expressed a corresponding wish to see you among them - A new method of admitting members is now in force and according to the new law the names of all candidates of this year must be given in before the first meeting in March - so that there is no time to be lost. The entrance money is $£ 10$ and the annual subscription $£ 4$. for which you may compound by a payment of $£ 60$ in addition to the $£ 10$. in all $£ 70$. - but if you have given a paper which is printed in the $\mathrm{Ph}$ [ilosophical] Trans[actions]. $£ 20$ is deducted from the composition money - so that you have your choice of paying the annual subscription for a year or two in expectation of sending a paper - or of clearing off all at once.

You had better send me a list of your publications with the place and date - for although I know them you can furnish me with a correct list with less trouble than I can make it for myself - I should not think of mentioning in the nomination paper more than two or three or your chief memoirs - but it will be well to remind me of them all.

[William] Baly called on me to ask after your place in Edin. - but he will not move till he learns Reid's ultimatum - I have written to Reid to ask him -

Syme is well and hearty - he went his round at the Hospital today for the first time - but he will not begin lecturing for a few days - He has been anxiously looked for by the students who are all glad he is come.

Tell me how you would like your copy of Quain's Arteries - I presume not folded-and merely loose in a portfolio - so that you can use them singly in Lectures -

You showed me a plan you had made of the fasciculi of the medulla oblongata could you favour me with a copy? Or with the original for a week or two that I may have it enlarged as a diagram and then return it.

Dr Allen Thomson

Yours very sincerely

W Sharpey

\title{
42
}

London May 18. 1848

My dear Thomson,

I have been tardy in thanking you for your kind attention in sending me the Embryo sheep - as well as for your long and agreeable letter but events have occurred here of such a disconcerting character that I must postpone for the present more sober matters -

You will have heard that a Dr. Mr. [sic] Cooper ${ }^{1}$ raised a storm against us, which together with the malicious comments of the Lancet had the effect of causing some 


\section{Letter 42}

effervescence on the occasion of the public distribution of the prizes ${ }^{2}-$ Still the tokens of disapprobation directed against myself and Quain on that day (for there were none against Syme who was well received) were mixed with a larger proportion of manifestos of a favourable kind - The hisses came chiefly from some of the men in Town formerly students but not now attending and the whole affair would I daresay passed over with little notice had Quain held his tongue.

For my part I cared not much about it because I felt confident that it was merely the safety valve and when the malcontents had cut their hiss the whole affair would soon be forgotten and things go on smoothly. But as you know Syme has taken the very inaccountable step of retiring. The grounds he assigns in his letter to the Council are first that he is satisfied he could not undertake the whole or any part of the course of Systematic Surgery without endangering the harmony of the School - and $2^{\mathrm{dly}}$, that if he did not lend his services in the systematic course and still retained his place in the hospital as Clinical Professor he would embarrass the Council in the necessary arrangements for the surgical department of the Institution ${ }^{3}-\mathrm{He}$ therefore sent in his resignation. $4^{4}$

Now he forwarded his determination on certain assumptions as you see and yet he gave neither the Council nor any one connected with the College any opportunity of explanation for he sent in his resignation and applied to the Lord Advocate for the Edinburgh Chair ${ }^{5}$ before he let me know what he was about. Moreover if he embarrassed the Council as he presumed by staying, he embarrassed the Council and us all infinitely more by deserting us. On my endeavouring to reason with him he generally ends by telling me that the step is taken irrevocably and that it is no use to say more.

He declares that he is perfectly pleased with the behaviour of his Colleagues towards him and even still more with that of the Students but he has done what he has done with perfect assurance that it is the right course.

You now know just as much as I do in the matter - except that he professes to think the Council wishes to urge on him to undertake the entire course of systematic surgery - now, whatever my opinion of the advantage of Syme's doing so might be, which I strongly stated to him - before I knew he meditated leaving, still the Council or rather a Committee of the Council merely desired to know whether in the event of its being deemed expedient he would be disposed to undertake the duty. I am sure they never thought of urging it on him - When I asked him his sentiments in the matter about three weeks ago he seemed pleased at the idea provided a suitable hour should be assigned to him. I wish to pass no opinion at all censuring him for the step he has taken but I lament it both for his own sake and ours.

What I have said between the first and last pair of double lines I would wish you in the mean time to keep quiet, for I fear any cause of irritation that might make matters worse.

Now among the rumours afloat there is one that I am looking after the Physiology Chair in Edinburgh and I beg you will be so kind as give such rumours if it reaches 


\section{Letter 43}

Edinburgh the most unqualified contradiction. I have never had any such intention and gave no one any reason to suppose so.

I can't help thinking that whether or not it was the best possible thing for Syme to move to London, it is an ill advised step now to turn back - I have every reason to believe that he was getting on most promisingly with practice. - All his Colleagues (except Cooper now no longer one) were pleased with his accession among us and ready to support him. The Students fully appreciated his value - and there was the most agreeable prospect of harmony and prosperity in store for us when all at once Syme makes a spectacle of himself and of us by his present move.

The people I trust will either find it unaccountable or take their own way of accounting for it.

You may congratulate yourself more and more that you have a quiet and comfortable prospect before you - which is secure against the caprice of anybody.

Yours very sincerely

W Sharpey

\footnotetext{
${ }^{1}$ Samuel Cooper (1780-1848), Professor of Surgery at University College London and Surgeon to its Hospital.

2 See the Lancet, 1848, i: 425 . In his farewell address to his students, Cooper complained of the conduct of "one or two of his colleagues" who had "exercised undue influence over the Council and the Senate - an influence which permitted them to assume an unjust power in all the proceedings of the College". The Lancet took up Cooper's cause and demanded that the vacant chair be advertised.

${ }^{3}$ Robert Liston, Syme's predecessor in the Chair of Clinical Surgery, had assisted Cooper in teaching the systematic part of the course until shortly before his death. Cooper had informed the College Council on 20 November 1847 that he would continue to require such assistance in the future (Council Minutes, 1843-53, vol. 4, 20 November 1847, University College London Record Office). When Syme's appointment was confirmed by the Council in December 1847, it was noted that "it is the desire of the Council to place him [Syme] in the same circumstances as Mr Liston, with respect to other lectures; but as by a previous Minute of Council the whole subject of the Chair of Surgery is to be taken into consideration in March next, no express arrangements can now be settled." (ibid., 18 December 1847).

${ }^{4}$ Syme's resignation was received by the Council on 13 May 1848 and accepted by the Committee of Management on 17 May. (University of London Committee of Management, 1840-51, vol. 3, Wednesday 17 May 1848). The "Cooper-Syme affair" is discussed at length in Taylor, op. cit., note 2 above (Introduction), pp. 246-51.

${ }^{5}$ Syme returned to Edinburgh in July 1848 to resume the Chair of Clinical Surgery, and remained in this post until his retirement in 1869.
}

\section{3}

London, $31^{\text {st }}$ Aug. 1848

My dear Thomson

It is perhaps just as well I did not write immediately after seeing the two letters of yours of which I have hitherto been so rude as to take no notice - There were sores open then which are now skinned over, and though you had no hand in inflicting them I could scarcely have avoided offending you with them in my correspondence - All I shall say now is that I am really sincerely happy that Syme's retreat from London has been so soon succeeded by his comfortable reestablishment in Edinburgh and that he is not likely to suffer either in circumstances or professional consideration by his untoward experiment. 


\section{Letter 43}

I presume you are well on with your arrangements for taking possession of your Kingdom in the West but perhaps before you move I may have an opportunity of seeing you as I start on Saturday for Dundee by the Steamer and mean to make Forfar my headquarters for a fortnight from which I may make a raid across the Forth for a day - I am just writing the last pages of the Anatomy so that like old Jeffray it will be finished at last - I wish I could have had you at my elbow not to nudge me to the work but to aid me with your good counsel on various points - but now it is done and "nescit vox missa reverti"l - faults must remain faults.

I hope you are proceeding with your Outlines of Physiology - your retirement from the Chair need not prevent you - it is rather indeed a motive - Your successor ${ }^{2}$ has been here, I had a long talk with him, but entre nous he seems to have notions of the duties of the Chair which in my opinion are rather suited to his own convenience than the requirements of the University. The [Monthly] Journal [of Medical Science] he tells me will be controlled by two able Editors. I am sorry for them for I am satisfied that the duty of editing a Journal is the most pernicious kind of occupation that a young man of promise can engage in, that is, if he writes in it. All that is gained is a readiness with the pen, desirable I grant, but not at the cost of gaining also the habit of hasty judgment.

I have still to thank you for the foetuses some of which I have given to Marshall for an inquiry respecting the foetal changes in the great veins with which he has been occupied - Quain's arteries arrived safe none the worse for the "pumice stone" of the Edinburgh "Socii".

I suppose Todd will soon be clamouring for "Development", before you come out with it I must have another "pull" at the Decidua now that the millstone of "Quain's Anatomy" is away from my neck -

Regnault ${ }^{3}$ the French Chemist is I hear occupied with a great inquiry on Respiration which will I hope furnish accurate data for the future - I am told the apparatus he uses (which was paid for by the government) cost not less than $£ 3000$ - it is said to be a masterpiece in its way -

I did not forget your inquiry as to a prosector - but on the whole I should think it will be better for you to take some one who is accustomed to the Scotch ways - You will of course perhaps have to try several before you get one properly to suit, what between conceit and ridiculous expectation, when they are clever or uselessness when stupid, it is no easy matter to make a permanent arrangement.

Poor $\mathbf{W}^{m}$ Macdonald ${ }^{4}$ has found his way here in the course of his Pilgrimage - what he will get to do I really cannot see - I suggested popular lectures at some of the Institutions and offered him diagrams - but he is unfortunately one of those for whom his friends can do little. -

With best regards to Mrs Thomson believe me

Your sincere friend W Sharpey

\footnotetext{
1 "Delere licebit Quod non edideris; nescit vox missa reverti": "the written word unpublished can be destroyed, but the spoken word can never be recalled". Horace, Ars poetica, I. 389.

2 John Hughes Bennett (1812-75), who became Professor of the Institutes of Medicine at Edinburgh in 1848.

${ }^{3}$ Henri Victor Regnault (1810-78).

${ }^{4}$ See note 5.3 above.
} 


\section{Letter 44}

44

35 Gloucester Crescent, London

4th January 1849

My dear Thomson

I wish you \& yours a happy new year.

Your letter was very agreeable as I longed to hear how you had fared. The account you give of your new flock has entertained me greatly, but I feel assured that with so earnest a teacher they will soon be thoroughly broke in to your own ways. I never had any doubt as to your success in fulfilling the duties of your chair or as to your commanding the respect and engaging the good will of your pupils \& I cannot understand on what grounds the men you could mention could have anticipated a different result.

When you kindly accompanied me to the Railway station last September you seemed to be anxious on my account, in consequence of the villanous [sic] attempts by the Lancet \&c. to stir up the Students here against me - I am glad to say there was not a murmur - I never was better received in my life, and matters have proceeded very smoothly, ever since - Arnott $^{1}$ was favourably received and is well liked as a lecturer and teacher - So far all is well - but I daresay you have heard that we have suffered a very considerable diminution in our new entries. Mine will be about 20 or 25 below the average of the two or three last years. Of course you can understand the reason as well as I.

I applied to my Colleague Mr Key ${ }^{2}$ to learn whether he could point out any person likely to answer as a Tutor to the little boy you mentioned. He had just then heard from Mr Wilkins a most intelligent Pupil of his own who was at Bonn that young Dr Gesenius a Son of the celebrated Professor of that name ${ }^{3}$ was desirous of spending some time in England but felt that his means would scarcely allow him to gratify his wish unless eked out by some literary or educational employment during his stay. At my desire Professor Key wrote to Mr Wilkins to ascertain through him whether such an occupation as you speak of would meet Dr Gesenius's views. Mr W had always written in the highest terms of Dr G's character and qualifications - He speaks of him as altogether a gentleman both in appearance and manner-well educated and accomplished, well acquainted with the English language \& with a decided taste for the study of our literature - I think he chose Chaucer's poetry as a subject for one of his academical exercises.

I herewith forward you a letter from Mr Wilkins in answer to Mr Key's inquiry as the most direct way of affording you the information we have obtained. After perusing it pray return it to me. You will see that it is important for Dr G. to know early whether his services would be required. To explain his readiness to accept a charge seemingly so insignificant for a scholar, I may mention that I authorized Mr Key to say that the pupil was the son of a person of rank and of high position in this country. ${ }^{4}$

As to my present occupation I have been looking again at the uterus but $I$ believe that there is not much more to be done at this juncture on the points which had previously been engaging my attention. The question of the genesis of the placenta I fear does not promise enough in return to make one devote much pain to its solution. I 
must next look to the condition of the inner surface of the uterus after parturition \& endeavour to ascertain with some exactness how much of the altered membrane comes away in the shape of the decidua. But really the day is so short and so dark and so cold, that I fear I shall do very little till the fine weather sets in. In the mean time I have examined the lining membrane very carefully in several uteri unimpregnated - some which had been so others which never had.

Many thanks for your second part of your book - which I see will be of great use to me when I come to the nervous system.

\section{Your sincere friend \\ W Sharpey}

Dr Allen Thomson

\footnotetext{
1 James Arnott, by then Professor of Surgery at King's and University Colleges, London.

${ }^{2}$ Thomas Hewitt Key (1799-1875), Professor of Latin at University College London.

${ }^{3}$ Friedrich Wilhelm Gesenius (1825-88), writer on English language and literature, son of the German orientalist and Biblical scholar Friedrich Heinrich Wilhelm Gesenius (1786-1842).

${ }^{4}$ Sharpey's letter of 7 March 1849 makes it clear that this "person" was none other than Lord John Russell. Thomson was still seeking a tutor for Russell's son in 1851 when he wrote to George Combe on the subject: Allen Thomson to George Combe, 18 April 1851, National Library of Scotland, MS 7321, f. 78.
}

\section{5}

\section{Gloucester Crescent (not Terrace)}

7th March, 1849

My dear Thomson

I greatly rejoice in the prospect of seeing you one of these days. I have a spare bedroom at your service and I need not say a thorough welcome. Though our dwelling is almost suburban we have threepenny omnibuses at our command in three directions - every $\frac{1}{4}$ of an hour \& some oftener - from nine A.M. till 11 P.M. The termini being within three minutes walk of my door.

I inclose for you a card of the meetings of the Royal Society for the present season, from which you will see that there is a near concurrence of a soiree \& ordinary meeting in the beginning of May - which I daresay will suit you, unless you could take the $19^{\text {th }} \& 21^{\text {st }}$ April. You cannot come amiss to my household whatever time you pitch on - but two or three days warning might enable me to make arrangements (scientific) which might render your visit more advantageous to you.

I can easily understand your hard work this winter, but your men will be broke in by another year-\& then, too, your rules and methods will have become almost venerable - a traditional authority as opposed to the right of private judgement, however objectionable in the synod, is the thing needful in the dissecting room whatever aid Ellis \& I can afford towards the compilation of your Rubrick will be cheerfully given - Do you wish me to send you down a copy of the rules as to turning \&c. which are followed here? or shall it be when you come up? Mind I don't think that the plan of operations established with us is the best. 


\section{Letter 45}

I saw Lady John Russell and had some further correspondence with Germany concerning young Gesenius, but after all he preferred travelling for the present $\&$ the matter ended - I was sorry, because I fear that Lady John may have lost time by our fruitless inquiry.

Todd is getting on somewhat faster with his opus viginti annorum - it is a weary affair \& I really grudge giving five shillings for what will bye \& bye be got for half price on the bookstalls - Reid's article on Respiration is sensible as might be expected \& not too long - but in the last $\mathrm{N}^{o}$ there are nearly two sheets given up to serous \& synovial membranes, ${ }^{1}$ an article written by a young man of merit but evidently a youth who has a conceited itch for writing - the easy confident tone of some young hands in the present day is not a little amusing. By the way I wished to look at a point concerning the swimming bladder of fish not long since \& had recourse to the recent article Pisces ${ }^{2}$ in Todds Cyclopaedia but after very carefully searching it through I could no where find even a surmise that fish possess such an apparatus! I daresay after all you will be in good time for I apprehend there are some heavy articles to come before $\mathrm{Z}$ is reached.

Have you seen the new London Medical Journal? Cormack ${ }^{3}$ is the unnamed Editor - Dr Williams ${ }^{4}$ the chief promoter \& Chancellor of the Exchequer (as I am given to understand). I confess my sympathies lie altogether with the previously existing monthly Journal ([John Hughes] Bennett's that was) which has now got a London Editor. Taylor \& Walton get some advantages as publishers of the New speculation but have taken none of the risk.

I am sorry to hear of Hutchisons ${ }^{5}$ backsliding \& misfortune; of course I presume he must be superseded - Would it in that event be infra dig: for the Professor of Midwifery to become director of the Institution? Why should it be so? Unless as to residence I see no incompatibility of the two offices being conjoined in one fit person, who has a taste for both.

Your former colleague Clark $^{6}$ is here on his marriage jaunt - I called today but he $\&$ his consort were out. Graham says the Lady has great expectations. [A]t any rate I hope she is good for Clark's sake for with all his peculiarities I have a great esteem for him.

I think there is a dissertation by some German or other on the anatomy of a stump, but I remember nothing professedly on the subject since the adoption of the existing views concerning the structure of nerves. I have just found the Dissertation I mean - The Title is "De mutationibus, precipice nervorum et vasorum quae in trunco dissecto [. . . ]" Auctore C. F. Probst Halle 1832 with 2 plates - On glancing it over I scarce think it will serve your purpose - all is done by coarse anatomy. Perhaps [Otto] Steinrueck De Regeneratione Nervorum Berlin 1838 will be more to the point - for he describes the structure of the swollen ends of divided nerves which have reunited by an intermediate new piece. Still he is more taken up with the new formation $\&$ the account he gives of the bulbous ends is not very elaborate. But Steinrueck's is an able performance altogether.

I observe that the learned \& worthy Dr Adams ${ }^{7}$ of Banchory Ternan has been adventuring on the famous question as to the Hunterian views on the structure of the placenta, and being apparently quite unnerved in the actual examination of such things, has got on the shoals. He argues that nature would never have made the maternal part of the placenta deciduous in man \& persistent in the cow - forgetting 
that no maternal cotyledon nor anything analogous remains in the human uterus after separation of the placenta-\& not knowing that we have perfect examples of deciduous maternal vessels in the carnivora. Perhaps you have seen his judgement concerning the William Hunterian or Guilmohunterian Preparations, if not, I promise you some amusement by its perusal - The worthy commentator on Paulus could never have injected a densely vascular structure or he never would have reasoned as he does. My friend Lee will I daresay think seriously about reviving his discovery which he has so long let quietly sleep!

Yours very sincerely

W Sharpey

\footnotetext{
${ }^{1}$ John Reid, 'Respiration', Todd's Cyclopaedia, op. cit., note 2.14 above, vol. 4, pt. 1, pp. 325-68; William Brinton, 'Serous and synovial membranes', ibid., pp. 511-41.

2 T. Rymer Jones, 'Pisces', ibid., vol. 3, pp. 955-1011.

${ }^{3}$ John Rose Cormack (1815-82), an Edinburgh graduate who moved to London in 1847 . He edited the Edinburgh Journal of Medical Science (1841-7), and London Journal of Medicine (1849-52).

${ }^{4}$ Presumably Charles James Williams (1805-89), Professor of Medicine at University College London.

${ }^{5}$ Possibly William Hutcheson, Physician and Superintendent of the Glasgow Royal Asylum. By 1850 he had been replaced by Alexander Mackintosh.

${ }^{6}$ Presumably Thomas Clark (1801-67), former Professor of Chemistry at Marischal College, Aberdeen.

${ }^{7}$ Francis Adams (1796-1861), physician and classical scholar. He published an article 'On the communication between the mother and the foetus in uteri', Lond. med. Gaz., n.s., 1849, 8: $150-4$.
}

\section{6}

London, 9th December 1849

My dear Thomson

I was most glad to hear from you - especially as your tidings were of an agreeable cast. I assure you that I felt anxious on account of my Glasgow friends in the doubt I had as to the possible effect of the Belfast College ${ }^{1}$ opening with so many allurements in the shape of exhibitions - in a district from which Glasgow was wont to draw no inconsiderable number of recruits - It was the Gown classes no doubt for which I chiefly feared and they have stood the trial.

Our school is much the same in point of new entries as last year - certainly not better yet still not above two or three under. This is bad enough - but it might have been worse all things considered.

You ask about Morton. ${ }^{2}$ There can be no inconsiderable doubt that his self criminating memoranda found after his death give the true solution of his last act. I have long been aware of his addiction to drinking - \& before I was aware of it it had become the subject of remark and of reproof by the Authorities of the Queen's Prison of which he was Surgeon - I dont doubt that whilst the consciousness of hopeless slavery to a degrading propensity was at the bottom of his despondency - this despondency so engendered displayed itself in respect to all his relations in life - In his professional position at the Hospital among the rest - tho' that must have been quite recent. He was depressed on account of the way Old [Samuel] Cooper his father in law settled his inheritance - leaving Morton no control over it - a fact by the way that 
seems to show Cooper's cognizance of Morton's pernicious habit, and say little for his probity in trying to put him into more responsible positions in the College. ${ }^{3}$ As to the letter of his friend $\mathrm{Mr}$ George, I regard it simply as a well meant effort to secure his (Morton's) reputation. Morton had been dining with him in the evening before he committed the deed. Mr George affirms (and I believe him) that Morton who was then depressed assigned no other cause than his prospects at the hospital - this only proves that, friend as he was to George, he did not give him his inmost confidence. Morton was making a better professional income than most of his contemporaries in the same line of practice - and in such circumstances how a sane man would destroy himself because he despaired of obtaining a certain hospital appointment is inconceivable. But it is but fair to say that I think he must have been deranged - there is an incoherence in much of what he seems to have noted down - which shows an estrangement of reason - and I have since heard that one or more of his family committed suicide and were addicted to drinking. It is all a lie to say that he became more easily [. . .] by drink from disappointment preying on his mind. So long back as August 1847 before Liston's [. . .] he was reprimanded by Cap ${ }^{\text {tn }}$ Hudson [?] the Governor of the Queen's Bench Prison for drunkenness - before the deputy Governor \& assistant Surgeon or apothecary. The last time I saw him which was one day in Summer he had evidently been drinking - and his conversation was abject drivelling - this was early in the afternoon. In short his was a case of suicide from drunkenness. -

I hope you find a spare hour and spare strength to do a little to your article for Todd. I say spare "strength" for I feel as I get older that I have not th: same physical strength to get through with work as formerly - Still it is a great matter to keep one's hand in - you have got through with some troublesome generalities - what comes next must be comparatively plain sailing \& familiar matter to you - Put it down and be not too fastidious - Give the thing its first shape at any rate and you may add or prune - or remodel parts with comparative ease. It would be great comfort to you to be able to say - "there it is in black and white - requiring some dressing to be sure - but existing in the body \& my mind is free[.]"

I hear very favourable reports of the revolution you have made in Glasgow College - for it seems to be little else - I know nobody who could have effected so much in the time. For myself, I doubt not I should have acquitted myself well enough of the mere professorial duties of your position - but I must frankly say I would not have done half of what you have done in the way of new organization. Without far more efficient aid than you have had I should have despaired of bringing order and neatness out of such a mess of rubbish - moral and material - as Jeffray left behind him. By the way I have looked at your regulations for dissection. They meet my view better than the plan we here adopt. The only thing I would suggest is to try the practicability of beginning the dissecting with the Perineum and superficial dissection of the face - then proceed as you prescribe - the brain to be preserved in spirits till convenient.

I have got a pamphlet from Syme on Medical Reform. ${ }^{4}$ [V]ery sensible-i.e. in pointing out causes of previous failures, but no way helpful with a remedy. Could the government deal with existing interests as Napoleon or Nicholas ${ }^{5}$ - the matter would have been settled long ago. Syme forgets that the Lord Advocate is not the Parliament - Mr Andrew Rutherfurd will not forget the difference in a hurry. Now 


\section{Letter 47}

Syme's plan is well enough if he could get it - but it needed neither a ghost nor a Regius Professor of Clinical Surgery to propose it. My plan and [sic] be one Examining board saluted if you will from all existing interests - to examine for license to practice. [H]olding examinations in England and in Scotland \& qualifying for both countries. The license to authorize practice in all aspects of the profession. Degrees to be honorary distinctions and to imply not merely professional but general education in larger [. . .]. Colleges of Surgeons \& Physicians to make members \& fellows in any way they like, but to confer no public privileges. Licences to be registered as well as all [...] professional titles, and controlled by any College of Physicians or Surgeons whatever. University regulations granting degrees to be sanctioned by the Crown which I suppose is visitor in most cases.

Who should make their appearance today but $\mathrm{John}^{6}$ and [. . . I was glad to hear from the latter that he was admitted at Balliol \& only waited for rooms. It seems strange that they should not have rooms ready for their scholars. The two youths promised to come tomorrow for dinner - so I shall hear all about Glasgow. With sincere regards to Mrs. Thomson \& your neighbours - believe me My dear Thomson

Your sincere friend

W Sharpey

\footnotetext{
'In November 1849, the Queen's College of Belfast began its first session; it offered courses in medicine from the outset.

${ }^{2}$ Thomas Morton (1813-49), Surgeon to University College Hospital and to the Queen's Bench Prison. He committed suicide on 29 October 1849.

${ }^{3}$ See letter 42. Cooper had tried to secure Morton's appointment as Professor of Surgery at University College upon his own retirement.

${ }^{4}$ James Syme, Letter to the Lord Advocate of Scotland, on medial reform, Edinburgh, Sutherland and Knox, 1849.

${ }_{5}^{5}$ Napoleon III (1808-73), President of France, and Nicholas I (1796-1855), Tsar of Russia.

${ }^{6}$ Probably John Thomson, William Thomson's son.
}

\section{7}

London, 14th January 1851

My dear Thomson

I have called on Halley and ought to have written you what I learned from him before now - but as he had communicated with Mr John Mylne, the delay is of less moment $-\mathrm{Mr} \mathrm{Ja}^{s}$ Mylne has had a more than usually severe attack of his almost habitual complaint - an affection of his breathing which Halley calls "congestive asthma" - His breathing you know is never very free, but now and then he suffers from exacerbations of his complaint. Dr Southey, ${ }^{1}$ a colleague in the Lunacy Commission, has seen him professionally along with Halley and coincides in Halley's views as to the nature of the malady as well as its treatment - They seem to look on the action of the heart as more feeble than natural - and there is some irregularity of pulse and irregularity of its force in the two arms - Still he is not considered in a dangerous state. I suspect Halley is quite right in ascribing the occasional returns of the more 
serious attacks to want of due care on the part of the patient - Mr Mylne when well - at least when in his habitual health - likes to see his friends - and enjoys chat over his tumbler when a friend looks in of an evening. Such little indulgences - of no moment to a strong man - derange his digestion, put him out of health and bring on his arthritic attacks - Again he frequently makes long railway journeys in the discharge of his duty - at hours and in weather unreasonable for an invalid. - Lastly he is rather a self-willed patient. I am glad to say however that according to Halley's account he was getting better of his present attack - and was become more tractable - Dr Southey had expostulated with him and he sees the necessity of using precautions to maintain health when he has it - A very good suggestion has been urged on him - namely that looking to the polycardial effects of exposure in his case - he should [. . . to arrange with his Co-Commissioners to take only metropolitan duty in Winter and do all his travelling work in Summer-and from what Halley says I dont doubt but that such an arrangement may be effected - Mr Macquorn Rankine ${ }^{2}$ called on me the other day - His fathers young ward has however decided on entering the Army, and his guardians have agreed to let him have his way-.

I yesterday received a letter from Nelson - and have this moment got his $\mathrm{Ms}^{3}$ by Mail - of course I have scarcely yet looked into it but from what I saw and heard in Edinburgh and especially from your opinion - I feel satisfied as to the importance \& value of the matter - and, seeing that he has purposely rewritten it as a paper for the Society I have no misgivings as to the form - However I will look it through \& give you a candid opinion - It occurs to me that as he was your Pupil and imbibed the taste for such researches from your instruction \& example, that the duty of communicating it will fall most appropriately \& gracefully to you - of course all you will have to do is to allow me to write "communicated by Dr A. T. \&c. \&c." at the top of it and hand it in to $\mathrm{Mr}$ Bell -

I am glad to hear that all your household except yourself are well - and I trust by this time the exception does not need to be made - The grand-nephew \& grand-aunt must add greatly to the amenity of your winter evenings - round the hearth of the Great Grandfather-a thought struck me forcibly on reading what you say of Miss Millar $^{4}$ - that the personal recollections of the representatives of a past age are well worth noting and preserving - Miss Millar could tell you much of the personal history (if I may so call it) of the University and Town - and it were a pity not to take advantage of her happy, cheerful and communicative disposition - to glean such information.

I am glad that Lawrie ${ }^{5}$ is succeeding in the College - I presume the influx of Andersonians are his Andersonian flock upon Andersonian terms - I have little doubt that he will strengthen your staff - but I should scarcely expect any large permanent addition of pupils from the Andersonian ${ }^{6}$ source, for unless I am mistaken the Andersonian subsists as a medical School chiefly by its smaller fees - and there will always be an average number of men decided by such a consideration -

Our entries are bad this winter, yet not worse than I expected - Still I feel it hard that whilst I discharge my duty with as much energy and as I trust efficiency as ever, I should suffer from causes which I cannot help.

The remarks on the Edinb $r$ Clinical Medicine Chair was a piece of foolish gossip sent 
from $\mathrm{Edin}^{r}$ to the $\mathrm{Med}^{l}$ Times and foolishly inserted by the foolish Editor - as for me I can truly say that it gave me very little disturbance. ${ }^{7}$

I have heard nothing more of Newport's $\mathrm{Paper}^{8}-$ but if you have reported favourably I have no doubt it will be printed. -

I have just finished the part of my course on digestion - and it is pleasing to contrast the manner in which we are now enabled to handle the subject compared with the confusion that prevailed a few years ago - Have you read the article "Verdauung" in Wagner's Handwörterbuch by Frerichs? ${ }^{9}$ To me it seems an able article - containing a good deal of original determination of doubtful points - very clear and methodical in exposition-full and yet not prolix - and not too much loaded with perplexing chemical formulae and disquisitions - The recognition of the real importance of the Saliva in digestion clears up much confusion and reconciles not a few discrepancies which previously caused mistrust. I suspect the clue to an explanation of the digestion in ruminants is to be got from a consideration of the special use of the saliva. Much of the amylum must be converted into soluble sugar during the thorough chewing and insalivation to which the food is subjected, and then what can be imagined better fitted for thoroughly drawing off this soluble matter by absorption than the many plies - The rennet then extracts the major part of the albuminoid matter. The want of acidity in the Paunch is quite in harmony with this view. -

I don't know yet well what to think of the sugar of the Liver - The fact that the liver yields sugar is no doubt true - I tried it last season when I got Bernard's paper ${ }^{10}$ \& showed the result to the class - but is the sugar formed in the Liver? That Sugar should continue to be produced in Carnivora which have been long kept strictly on animal food - is startling at first - still it is not more remarkable than the production of milk containing sugar in a nursing lioness.

I wish I knew more of chemistry!

Have you got Kölliker's Microscopische Anatomie? ${ }^{11}$ It shows a vast amount of work.

I fear we shall never see another number of Goodsir's Annals [of Anatomy] - What ought to be done? A record of the kind is wanted. Goodsir has occupied the field, and others were willing to leave it to him as he had taken up the position - but three numbers are due without explanation of the arrest.

I do not see the Edin. Monthly - but I fear the exclusive plan will not answer ${ }^{12}-\mathrm{A}$ Journal should be something more than the organ of a particular school - it should be catholic in its objects - One fault of the Edinburgh men is, I think, that they hug one another too much - then when they happen to fall out there is the more bitterness - Goodsir is free from that fault, and Simpson is above it himself, though his great merit serves to engender it in others - affording them something to boast of - Our friend Syme is greatly responsible for it in both ways - and Christison from narrowness of view. - As it is I am satisfied the feeling is decidedly prejudicial to progress - Self satisfaction no doubt is a satisfactory feeling to all men - and in all pursuits - and it helps to make men bold in scientific speculation - but these advantages are more than balanced by inevitable one sidedness - and security. Of course you will not mistake the spirit in which I thus speak of most estimable men and valued friends - with whom I would be happy to make one of a group - and not the less because I flatter myself that 
my stay in London has very effectually eradicated from me any tendencies of the kind alluded to, if I ever had them. But there seems no chance of Bennett making an opening for the present ${ }^{13}$

In speaking of Lawrie I might have minded to tell you that our new man Erichsen ${ }^{14}$ has turned out a good appointment - He is a good lecturer and a neat operator - with agreeable and conciliatory manners. The students are getting much attached to him - He is young - but the fault speedily mends itself -

I had very nearly forgotten to refer to a letter which I received the other day from the General Secretary of the British Association Mr Phillips ${ }^{15}$ (and doubtless you have got one of the same) intimating my appointment as one of a Committee along with Goodsir, Laycock ${ }^{16}$ \& yourself to report on the recent progress in the Anatomy \& Physiology of the Nervous System - It occurs to me that we should divide the "bundle of sticks"[.] I will be glad to take the histology of the subject, as Bennett and the Germans phrase it, Laycock might take the physiology - and you \& Goodsir divide between you the special anatomy of the nervous centres the Comparative Anatomy and the Development. Each thus undertaking a department of a vast subject, and each in the end having the whole submitted for his approval or suggestions - If we really do undertake so much unpaid labour - this will I think be the best way of getting through it - so that the yoke may be borne with tolerable fairness by each - What thinkest thou?

As the meeting of Parliament approaches we hear the note of preparations for new attempts at medical Bills - notwithstanding the fear of Rome - For myself I have for long ceased to think of such matters - finding that all projects of medical improvement through the legislature have hitherto ended in smoke - I feel that it will be time enough to trouble oneself about them when there seems a prospect of serious action.

Mrs Colvill and Mary are happy to hear of you - and beg to send their kind remembrances.

And recommending myself with sincere regards to Mrs Allen and Miss Millar as well as your brother William and all his fireside, not forgetting my young friend Miss Helen - I ever remain My dear Thomson

$$
\begin{gathered}
\text { Your affec }{ }^{t} \text { Friend } \\
\text { W Sharpey }
\end{gathered}
$$

Dr Allen Thomson

\footnotetext{
${ }^{1}$ Henry Herbert Southey (1783-1865), an Edinburgh graduate who had been a Commissioner in Lunacy since 1833.

2 William Macquorn Rankin (1820-72), civil engineer and natural philosopher.

${ }^{3}$ Presumably Henry Nelson, 'The reproduction of the Ascaris Mystax', Phil. Trans. R. Soc., 1852, pp. 563-94.

4 One of the sisters of Thomson's mother, Margaret Millar. Their father John Millar was prominent in Scottish political and cultural circles in the late eighteenth century.

5 James Adair Lawrie (1801-59), Professor of Surgery at Glasgow University since 1850.

6 The Andersonian College, founded in 1796, was a rival in Glasgow to the University. Its medical school remained independent until the twentieth century.

${ }^{7}$ A reference to a report of 28 December 1850 that Sharpey was to return to Edinburgh as Professor of the Institutes of Medicine after John Hughes Bennett had been translated to a new Chair of Clinical Medicine. See Medical Times, n.s., 1850, 1: 678.
} 


\section{Letter 48}

\footnotetext{
${ }^{8}$ Probably George Newport, 'On the impregnation of the ovum in the Amphibia', Phil. Trans. R. Soc., 1851 , pp. $139-42$.

${ }^{9}$ F. Th. Frerichs, 'Die Verdauung', Wagner's Handwörterbuch, op. cit., note 30.2 above, vol. 3, pt. 1, pp. 658-871.

${ }^{10}$ Claude Bernard, 'De l'origine du sucre dans l'économie animale', Arch. gén. Méd., 1848, 18: 303-19. Bernard's claims concerning the glycogenic function of the liver were at first controversial.

${ }^{11}$ Albrecht von Kölliker, Mikroskopische Anatomie; oder, Gewebelehre des Menschen, 2 vols., Leipzig, W. Engelmann, 1850-4.

${ }_{12}$ There was, presumably, some suggestion that articles to the Edinburgh Monthly Journal of Medical Science should be provided exclusively by members of the Edinburgh school; I have been unable to find any reference to this proposal in the journal itself.

${ }^{13}$ This remark shows that Sharpey was still considering a return to Edinburgh - on this occasion as Professor of the Institutes of Medicine. See Duns, op. cit., note 51 above, (Introduction), p. 360, which reveals that Simpson and some of the other Edinburgh Professors were keen for Bennett to take over the Practice Chair "in order that we might get Dr. Sharpey down by this arrangement to our University".

${ }_{14}$ John Eric Erichsen (1818-96) was appointed Professor of Surgery at University College London in 1850.

${ }^{15}$ John Phillips (1800-74), geologist and one of the founders of the British Association for the Advancement of Science.

${ }^{16}$ Thomas Laycock (1812-76), lecturer on clinical medicine and writer on the physiology of the nervous system. He became the Professor of the Practice of Medicine at Edinburgh in 1855.
}

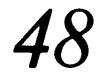

Private

College, Glasgow

19th July 1852

My dear Sharpey,

You have heard of course of Old Thomas Thomson's death and I daresay may through Graham know something of the canvass. From living in the country and seeing very few people I know nothing almost of what is going on.

Immediately after the death some of my medical Colleagues who are attending my Lectures on the Textures (instead of resigning as they threatened on my appointment) placed before me for signature a very high testimonial for Dr. R. D. T. ${ }^{1}$ already signed by the whole six, Macfarlane' ${ }^{2}$ name not being there as he is not yet inducted. I demurred on the ground first that I never interfered with appointments in the University to which I belonged, and when pressed to sign it because of his having already been in the University and having established a claim; I gave them my real and decided opinion that he was not the man to confer reputation on the University or to teach the class efficiently. I then learnt not much to my surprise for I knew the fact already that their opinion was exactly the same as mine viz. that personally he was a very estimable man but \&c. \&c. and that this was only to keep out any worse man. Who they pointed at I do not know but the principle among my Colleagues \& in Glasgow generally of "Our own fish guts \&c." is remarkably strong and is heightened by a strong Edinophobia. I think it is with some the fear of breaking in upon the nice snug way of granting degrees, and with others a general prejudice.

I saw how disagreeable a position I was to be placed in and at first agreed to sign a moderate testimonial merely stating that we were satisfied with the manner in which the duties of the class had been conducted, which was all we as professors had to do 
with: but even that I knew was a little strong and so on reflection as I saw I had no right to dictate terms to the others I declined simply to sign on the first grounds of noninterference which I had stated to them. At the same time stating my personal regard for Dr. R. D. T.

A great push has been making for him. The old tory way of making appointments through the Duke of Montrose ${ }^{3}$ has been revived since the accession of the tory ministry, and I believe the old Principal who has renewed his youth on the occasion has been seeing visions of the entire recovery of the ascendancy of the Church and tory party in the College. The last appointment of Macfarlane was made entirely through him. We have yet to see what is to turn out of that appointment. He never was famous as a Lecturer and only gave a few lectures on Clinical Surgery long ago and he is not understood to have been reading much since that time.

The Principal is reported to have said that if Mr. [Thomas] Graham was not in the field, he would recommend Dr. R. D. T. You may believe I feel very anxious in regard to this appointment. If a good man is placed in this chair there is some chance of our medical school rising out of its present state, and the University will derive eclat from the new professor in so important a position as a good man will occupy in Glasgow and in the scientific world generally: but if we are to have nothing better than heretofore, adieu to anything like a revival of the school or the system of teaching, and all reflected credit on the University from the occupant of the chair. I need not conceal from you that what with William [Thomson]'s death and the appointment of his successor, if the Chemistry chair were to undergo no improvement I should feel myself quite alone in the University and would have scarcely any tie to it but the salary paid to me.

I do not know in the least what are Graham's emoluments from his office or from other sources in London: and he must know pretty well what those are connected with the chair in Glasgow. The salary is $£ 250$ : The fees are at present, I suppose about as much or more, and might be at least doubled; and I understand the income is doubled by references and Analysis which of course in good hands would also increase. It is no doubt the most important Chemistry Chair in Scotland if not in the country, and if Graham thinks it his interest to apply for it or only to signify that he would accept of it, there can be no doubt he would get it and would make a capital thing out of it. But you must have gone over all this with him already, and I am anxious to know what has been passing with you on the subject.

Thomas Anderson ${ }^{4}$ and your old pupil Blyth ${ }^{5}$ are candidates, and they are both excellent men. Free kirkers \&c. are excluded as the tests are inforced. I have no idea who more may be in the field - in fact I am very ignorant of what is doing: but I argue rather favourably from the delay that seems to be taking place, and conclude that the claims of candidates must be under consideration. The principal has been seemingly ill too for a few days which may have assisted in putting off any immediate appointment if it was to depend on him.

I have a deal to say to you. When may we expect to see you down? You will have your room either at Greenhall with Mrs William or at Millhaugh where Mrs Allen and I sleep, on account of Miss Millar who is now becoming somewhat infirm.

I am hard at work with development for Todd. He has printed two sheets and I have advised him to bring out a short number and give me a little more time for the 
remainder. I wish it were out of my hands[.] I shall feel a great load off me. It is like a constant night and day mare on me.

I need not tell you that all my grumblings as above are only for your most private ear, so I beg you will burn them as soon as read, and let me have your news as soon as possible.

I have a little private story about a memoir of William \& the Edin. Monthly journal which will interest you when I have time. It is sent to the Medical Gazette and Times \& will appear shortly.

\section{Ever my dear Sharpey \\ Your sincere friend \\ Allen Thomson}

Remember we count on your coming down and staying as long as you can to gather mushrooms and health, and to leave behind you consolations and contentment among the grumbles.

\footnotetext{
${ }^{1}$ Robert Dundas Thomson (1810-64), nephew of Thomas Thomson. He assisted his uncle in the teaching of the chemistry class from 1848 .

2 John Macfarlane (1796-1869) succeeded William Thomson in the Chair of Medicine at Glasgow.

${ }^{3}$ Both the third and the fourth Dukes of Montrose held the office of Chancellor of Glasgow University. The former had been instrumental in Thomas Thomson's appointment to the Chair of Chemistry in 1818 . The fourth Duke, James Graham (1799-1874), was a staunch Tory.

${ }^{4}$ Thomas Anderson (1819-74), a lecturer in the Edinburgh extramural school, eventually succeeded in the Glasgow Chemistry Chair.

5 John Blyth, Professor of Chemistry and Practical Chemistry at Cork College.
}

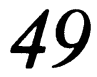

London $20^{\text {th }}$ July 1852

My dear Thomson,

Your agreeable letter has just come to hand and finds me much in the humour for writing you a reply - for indeed I had been actually meditating on the expediency of sending you a missive for the last two or three days. It is true I have little to say of myself - but let that little be first said. Having long felt the difficulty of mastering (I mean rightly understanding \& retaining) the results of modern physiological chemistry, I have e'en begun again at the beginning and worked for the last three months as a humble practical pupil in the Birkbeck Laboratory, deeming practice (always accompanied with an inward ratiocination) the best means of attaining my end - I thought it best to go through the entire of inorganic analysis before tackling the Animal Chemistry and am already tolerably expert in qualitative analysis. I shall continue the work as I can find time which I hope to do for 2 or $\mathbf{3}$ hours a day during the busy season. I have been greatly pleased with the occupation which I find a most salutary mental exercise. My only fear is forgetting it all too easily again. Another object I had in view was to judge for myself how far practical Chemistry (studied in a Laboratory) can [. . .] be recommended to the better class of Medical Students. 
Now on the strength of my chemical proficiency I am not going to offer for the Glasgow chair, just yet, but in consequence of my pursuit I have been thrown somewhat more than usual among those who are capable of forming an opinion of the candidate and are not slow to speak it out - and the first remark I will make is that I was greatly pleased and indeed proud to think that my friend Allen Thomson had not lent himself to, but, exercising the moral courage he possesses, had abstained from the very lamentable proceeding of his medical colleagues in regard to the vacancy. Were I Walpole I would discourage the system of introducing sons \& nephews as assistants in the hope that a convenient opportunity would be found for fixing them on the Institution-positively I would prefer an equally good candidate free from this objection - and I assure you I have heard various independent persons express a similar opinion -

Graham is quite a settled denizen of London - he is much more in London society than I am - he is a man of independent property - and as to consulting chemical practice he might have as much as he likes - For some years back he has except in particular cases (Government Commissions and a few others) declined that kind of work - and gives himself almost entirely up to scientific inquiries - The business of assaying in gold \& silver as a control on the Mint and for the Bank of England he manages through a highly intelligent assistant who is quite up to the routine - This business itself has vastly increased of late so that he will need some additional help.

I mention this to you to show that the prospect of practising as a consulting Chemist would not take him to Glasgow - and although attached to his native town, he keenly relishes London life and the Scientific Society here - moreover he is much devoted to the University College, so that he is out of the question.

Here we look on Anderson as the probable winning horse, and most likely to reflect credit on the Glasgow University by his scientific eminence. Blyth is also well thought of especially as a teacher - Sir R. Kane ${ }^{1}$ was here the other day - I did not see him - but he spoke to Graham in the highest terms of Blyth and of his services in the Cork College. Williamson ${ }^{2}$ seems to look on Anderson as having better claim than Blyth on the score of original working. But, out of all the names mentioned I have not heard a word in favour of $R$. D. T. Of course, I need not ask you to keep my remarks quiet as I have no mind to meddle in the matter or to commit other people by repeating their opinions.

The Principal is a sworn friend of Graham's uncle and Minister of Killearn - and I understand he has answered applications for his interest saying that he will support Graham. Now perhaps this is to get rid on easy terms of importunity - or it may be earnest - but in any case he can hardly be committed yet to R. D. Why should not Anderson not apply to him and refer him to Graham for an opinion?

I hope Todd will not comply with your request - Depend on it it is better to be forced to get through with a task which has become irksome.

It seems that the case of Lizars versus Syme is really to come into Court - about the end of the month - Will the verdict - whichever way it be - alter the position of the parties in publick estimation?" $?^{3}$ Quarrelling is "a fault" but to carry professional quarrels into a court of law is worse - it is "a blunder" - or as I would rather say it is sheer folly; and I am glad in this case that Syme is not the pursuer. Syme would meet 


\section{Letter 49}

with more concurrence but for the spirit in which the reviewing especially of surgical works is conducted in the Edin. Monthly. But I have often said before the great mistake of most of the Edinburgh men is that of self complacency. You have all need of each other - all, the best of us much to learn - and the worst may not be utterly incapable of helping the best on an occasion.

I am glad to say that after an unpardonable delay Nelson's Paper is being printed in the Phil Trans. - I will tell you more of it when we meet - I have now beside me a lengthy MS. by Newport ${ }^{4}$ - In his former researches he could never observe the spermatozoa any deeper than the surface of the enveloping jelly of the ovum. One day that he was showing the fact to me I noticed two or three spermatozoa at a considerable depth within the jelly - tho' not in the interior of the ovum, soon after Mr T. Bell and Mr Busk ${ }^{5}$ who had gone like me to see his expts. noticed abundance of the creatures (or plants) deep in the jelly - and since then Newport has seen it to be common, \& has sent a supplementary communication to the RS. corrective of his former Paper - He is a most expert dissector and manipulator of minute objects - but my faith in him generally as an observer begins I confess to waver - I never cared much for his attempts at higher generalization in Physiology - I must however say that excepting in that point referred to I found all the matter he showed to us to be as he had described them.

I will gladly avail myself of your invitation again to enjoy a retreat to Clydeside with your good converse \& companionship. You know I am tied here till the Examinations at the Univ: of Lond. are over - that is till after the third week in August -

With kind remembrances to Mrs Allen Mrs William \& Miss Millar

Believe me my dear Thomson

Ever your sincere friend

W Sharpey

\footnotetext{
${ }^{1}$ Robert John Kane (1809-90), Professor of Chemistry at Apothecaries' Hall, Dublin from 1831 to 1845, and subsequently Professor of Natural Philosophy to the Royal Dublin Society.

${ }^{2}$ Alexander William Williamson (1824-1904), Professor of Practical Chemistry at University College London.

${ }^{3}$ In 1853 the long-running feud between Syme and John Lizars (1787?-1860) again led to litigation. On this occasion it was Lizars who claimed that he had been defamed. See John A. Shepherd, Simpson and Syme of Edinburgh, Edinburgh and London, E. and S. Livingstone, 1969, pp. 126-7.

${ }^{4}$ George Newport (1803-54), London surgeon and naturalist. His paper 'On the impregnation of the ovum in the amphibia' appeared in the Proc. R. Soc. Lond., 1850-4, 6: 214-7.

${ }^{5}$ Thomas Bell, one of the Secretaries of the Royal Society; and George Busk, a Fellow of the Royal Society.
} 


\section{0}

Wrote 26th [This is in Thomson's hand.]

35 Gloucester Crescent, London

19th May 1854

My dear Thomson

Under an uneasy feeling that I owed you a long letter with information on various matters which I had promised - I have been actually deterred from any intensive communication for nearly a twelve month!

Leaving yet a little while that more full communication contemplated - I am induced to write on the present occasion by Dr. Tweedie who asked of me to forward you the inclosed documents respecting Dr. Kirkes ${ }^{1}$ candidature for the Assist $^{n}$ Physicianship to St. Bartholomew's Hospital. Baly, his Senior is unopposed, there being two vacancies. Kirke's opponent is the son of one of the Old Physicians of the Establishment; Dr. [Clement] Hue and carries with him all the influence among the Governors which nepotism (rarely pure \& undefiled by personal claim) can command. The Hospital Medical \& Surgical Staff are to a man supporters of Kirkes - and they as will others of his friends are endeavouring to bring public opinion to bear against the close [sic] system - Dr. $\mathbf{K}$ has accordingly applied to various medical authorities of weight, for testimony in his favour and has been already very successful in obtaining it. It is not considered of much use to have such testimony from men in London connected with Hospital or Educational Establishments (I mean beyond that already given) inasmuch as the lay governors will merely look on such as evincing as esprit de Corps of the Medical bodies in London as opposed to lay patronage - In reality it is a manifestation against the dominancy of personal favour.

Inclosed is a printed document which has been pretty extensively signed by medical men out of London and Dr. Kirkes is very desirous of obtaining your testimony to the same effect - As it is adapted for Hospital officers - perhaps the best way will be either to make such alterations by erasure \&c. as will suit it for you - or to write out a certificate of the same import - mutatis mutandis - This will save you the botheration of compounding a testimonial, which is to me very sickening work -

Your nephew John is here at present. He has been twice at the R[oyal]. S[ociety]. and has been introduced to the President's Soirees where he has met with several leading Engineers and men of science much interested in his present undertaking. He spent a couple of days with Admiral Smyth ${ }^{2}$ down at Aylesbury - who told me he is greatly pleased with him.

We are approaching to a close with our Session at the R. Society \& I have got on very pleasantly in my post. You will have received the first two numbers of the Proceedings in their new dress, and should you have any brief communication suited for them I will be happy to receive it. We desire to give early $\&$ brisk circulation to all that is sent to the Society - and in particular we wish it to be known that an author may send a scientific communication - to be read to the Society \& published in the Proceedings although he may not think it of sufficient importance to appear in the Philosophical Transactions - Or should he in the progress of his inquiry fall in with results deserving of being made known in the mean time they will be received \& published without any 


\section{Letter 51}

prejudice to an embodiment and more full exposition of them in a more elaborate memoir which he may subsequently present for the Transactions.

Yesterday I fell in with Mr Charles Henry at the R. S. apartments. He inquired after you and after Williams family with great interest; and expressed himself in very grateful terms respecting the attention and kindness he had received at 80 George Street.

Are you likely to be here soon?

With kind regards to Mrs Thomson

believe me always

my dear Thomson

your sincere friend

W Sharpey

Dr Allen Thomson

P.S. You had best send the document for Dr Kirkes to his own address.

2 Lower Seymour Street Portman Square

This will save time.

WS

Our Medical School has rather improved this winter, there having been a small increase (8) in our new entries.

\footnotetext{
${ }^{1}$ William Senhouse Kirkes (1823-64), Demonstrator in Morbid Anatomy at St Bartholomew's Hospital since 1848. In 1854 he defeated John William Hue in a contest for the post of Assistant Physician to the hospital:

2 William Henry Smyth (1788-1865), admiral and scientific author. He was especially interested in astronomy.
}

\section{1}

Wrote 17th [This is in Thomson's hand.]

London, 15th August 1855

My dear Thomson

I should have written before now to say that, unless I have been forestalled by more distinguished candidates, I mean to be your guest during the Meeting of the British Association [for the Advancement of Science].

I shall suit the time of my arrival to Mrs Thomson's convenience entirely - for I daresay her arrangements will require no little management - You know I dont care how I am stowed away.

To finish with my own plans - I have been harassed all Summer \& incapacitated for work by a irritation of "boils \& blains" which have perseveringly kept up a continuous warfare against me - one healing and another coming on - like the reinforcements in the Crimea - I have tried various prescriptions but without any marked benefit. In these circumstances I think it will be best for me to get away to the north as far as Dee Side in the first instance - so soon as I can get away from here - and then go to Syme a 
few days before the Glasgow work - or else go to you before \& to him after it is over - but I think it will be best to go first to him. All this however as far as Glasgow is concerned is subject to your arrangements - I mention this particularly on the present occasion because of the turn about in your household which the Sorners [i.e., sojourners] of the Association will necessitate.

Next as to a more important Guest. I have a letter from Kölliker from Würzburg - in which he informs me he will come to the Glasgow meeting. He proposes if my arrangements suit to travel from London with me to the meeting. From what I have already said you will see that I must be out of London long before that time. But the point is to have quarters for him in Glasgow - Now I dont know whether you will or can take him in - but I presume there will be no difficulty in having him hospitably received in some private house, and I would be glad if you would arrange this and write to him to that effect. He leaves Würzburg today or tomorrow, will be a fortnight in Paris \& will arrive in London $\mathrm{ab}^{t}$ the $1^{\text {st }} \mathrm{Sep}^{t}-\mathrm{A}$ letter will reach him in Paris addressed "chez M. Dumont. 6 Rue Vivienne." I will write at once to Kölliker to say that you will inform him where he will be received in Glasgow. -

I am just packing up to go to another residence - I have been 11 years where I am \& wish to get nearer again to the town \& to my work - accordingly I move to 33 Woburn Place - where after Friday letters must be directed. The House is larger than I want \& yet I could not find one with such accommodation as I wished unless a large one - I intend to take a Pupil to reside should I find a proper one - so as to take off part of the rent - and I hope to have more elbow room - Moreover we shall always have quarters for you \& Mrs Thomson whenever you like to honour London with your presence -

I have just heard that Alison has resigned - and that Bennett is likely to try for his place - Should he be successful of which I have great doubts - the chair of the Institutes would be vacant $\&$ this might require me to put a question to myself - What do you suppose might be reckoned on as the income from the Chair \& Graduation Fees? Bennett is here \& I was asked by Tweedie to meet him to day at dinner as he wishes particularly to see me - But as I wish particularly not to see him, that is not to involve myself by any talk on the matter, which might afterwards give rise to misunderstandings \& require explanations - I have excused myself.

Bennett made a great mistake in choosing Edinburgh for the scene of his activity - His merits are of a kind which would have told much more with the London Public - I mean of course in practice.

Your niece Helen Thomson called here the other day - Mary was unluckily down at Woolwich - \& since then has been so taken up with getting our house in order that she has been unable to call. I hope we shall repair this delay however before Helen leaves London.

$$
\begin{gathered}
\text { Yours very sincerely } \\
\text { W Sharpey }
\end{gathered}
$$

P.S. I need hardly say I do not wish to seem to be actively interested about the Edinburgh changes - for after all it will be time enough to think about the matter when Bennett moves - if that ever happens. Should Christison wish the place I daresay he 
would get it before Bennett and I think there will be candidates from here - You will see that the question I put to you is done quietly in order to be furnished with a reliable statement of the return of the Class.

What effect has the new regulation (admitting a proportion of extra academical lectures to qualify for the Degree) had on the Edinb. College Classes? ${ }^{1}$

W.S.

${ }^{1}$ See note 30.5 above.

\section{2}

Ballater, Deeside

$2^{\text {d }}$ September 1855

My dear Thomson

Your letter addressed to me at London (of the $27^{\text {th }}$ aug.) reached me yesterday after making the circuit of London \& Edinburgh. I came to Edinburgh on Monday evening by the express train - Staid at Millbank all Tuesday - saw nobody but the Symes came to Arbroath on Monday and here on Thursday night. Here I found my Sister $\mathbf{M}^{r s}$ Martin of Dundee \& her husband - in Lodgings. I am in the Hotel. Syme must have me back in Edinburgh to dinner on Wednesday - so that I must leave this Tuesday morning. I will come to you on Wednesday the $12^{\text {th }}$ or sooner if I can get away. I will let you know the time beforehand.

You allude to the ongoings in Edinburgh - I suspect Bennett is too unpalatable with the Profession there to succeed, with all his backing, I guess too that he is over urgent and not over discreet. I shall be satisfied either way. I made up my mind that if the opportunity of moving to Edinburgh offered itself I would not let it go past - but should there be no opening I am quite contented. In the mean time I have told Syme that I wish to remain quite passive. I have no desire to press myself upon the choice of the Patrons - Still less to mix myself up with Bennett's plans. I thought it right to state plainly that my services were at the command of the Patrons if they desire them, but beyond this I do nothing - and whatever happens I shall be sorry if "ill blood" should be engendered between estimable people on my account.

I think I have been improving for the two days I have been here - I have had a tolerably long walk one day \& have twice ascended rather respectable sized hills without in any degree overworking myself. Indeed I think I have a fair prospect of getting set up again for the winter - if people would mercifully and considerately allow a poor invalid to dispose of himself in his own way. As to the [British] Association I am right glad our head quarters are to be at Greenhall and I shall beg to be left at liberty to go \& come to the scientific fair as I find agreeable and convenient. Above all I beg you will not confer on me any office which would require attendance on a Section - as I am quite unfit for confinement or for exciting work - indeed I shall rather than subject myself to that, cut the concern altogether $\&$ enjoy peace \& quiet. 
I saw Retzius ${ }^{1}$ in London. He \& his Prosector are to set out for Dublin - thence to go to Belfast \& finally to Glasgow - I doubt if he had got your letter - I mean a private Letter from you - for he had received a Public Invitation - Carpenter promised to write you about him.

Dr Allen Thomson

$$
\begin{gathered}
\text { Yours very sincerely } \\
\text { W Sharpey }
\end{gathered}
$$

${ }^{1}$ Anders Adolf Retzius (1796-1860), Swedish anatomist and anthropologist.

\section{3}

33 Woburn Place, London

15th October, 1855

My dear Thomson

I begin to fear that if I do not write this afternoon (even in a hurry) there will be another week's delay in letting you hear from me.

And first as to the Drawings ${ }^{1}$ - Your Letter was addressed to Edinburgh \& did not reach me till Friday morning - I wrote $\mathrm{Mrs} \mathrm{W}^{m}$ that day by return of post, decidedly advising the disposal of the collection in the way suggested and with an abatement in the price originally approved by myself - in consideration of their present intended \& possibly final destination you will likely see the Letter so I need say no more of it.

After leaving you I spent the remainder of September at Broughty Ferry except the last four or five days - as I came up by Sea $\&$ could not cut so close as by rail. Before leaving Scotland I was in good measure prepared for Bennett's defeat - but I confess not for Laycock's success - True, I had been assured on fair authority that Simpson had taken his side - but really I could not allow myself to think that this was the real case, without a supposition as to Simpson's character for fair dealing, that to me was inadmissible. It was quite open to our little friend to further the cause of Laycock or any other Candidate he preferred, but this I considered to be quite incompatible with the language he used $\&$ the professions he made.

You will believe me and be pleased when I assure you that I heard of the result with perfect equanimity. An opportunity had offered (in a certain contingency) of my moving back to Edinburgh and Edinb ${ }^{h}$ friends, it was necessary I should decide what I should do \& make known my decision - I concluded that the opportunity should not be allowed to pass \& patiently waited the result, not anxiously desiring the change nor with sanguine thought as to the event $\&$ consequently the event caused no mortifying disappointment.

M[ary] has had a pleasant ten days with Kölliker as an inmate of the house - only I wish we had had one quiet dinner by ourselves at home - He left us yesterday Morning - thoroughly pleased with his visit to Britain \& full of kind remembrances to 


\section{Letter 54}

yourself - Mrs Allen - the young Ladies \& all other northern friends - He read to us $\mathbf{M}^{r s}$ Allen's Letter which greatly gratified him - The approach of Post time and the end of the paper warns me it is time to say how completely I am

Your sincere Friend

W Sharpey

${ }^{1}$ Presumably William Thomson's collection of teaching illustrations.

\section{4}

33 Woburn Place, London

27th Oct. 1855

My dear Thomson

I wish you would help me to find as soon as possible four more Acting Assistant Surgeons for the Turkish contingent. ${ }^{1}$ The pay of and appointment is $10 / 6$ a day, and if the candidate has a Diploma \& gives satisfaction in the service - he will have a good chance of promotion to a higher rank. He will have a free passage out \& home, lodgings or lodging money, free rations except when on board ship. He must agree to serve a year if required and will be guaranteed a year's pay $\&$ should his services be dispensed with after a year's duty he will receive a gratuity of half a years pay -

In case of being disabled by wounds or accidents received in the execution of duty - he will be guaranteed a pension.

We had a nice letter from Kölliker yesterday - He found all his people well -

It is rather curious that our Medical School (at Univ. College) should have made a considerable rise this year I have Sixty five new men which is more than I have had since the year of Liston's death (1847). The average of new entries for some years back has been about 50 - It will mean an addition of about $£ 100$ to my emolument \& I may glean a straggler or 2 before the end of the Session -

My enemies [i.e., his boils] have been very vexatious since I saw you. They have now retreated in great part to my back \& some nights have made it difficult for me to find a position to rest in. Generally, however my health keeps good - I have sometimes thought that my present trouble is sent to punish me for not enough valuing the robust health I have up to this time enjoyed - They interfere not a little with every kind of exertion both bodily and mental.

With sincere regards to $\mathbf{M}^{r s}$ Allen -

I am ever My dear Thomson

Your sincere friend

W Sharpey

Dr Thomson

${ }^{1}$ I.e., to act as military surgeons in Turkey during the Crimean War. 


\section{5}

33 Woburn Place, London

5th December, 1855

My dear Thomson

I am glad to accept your proposal for a weekly interchange of letters - as we can neither receive nor dispatch letters on Sunday - it would seem that my day for writing should be before or after the Sabbath as you call it in the North - but that is little matter - \& perhaps my plan is to write on Sunday \& add a word if necessary on Monday before posting.

In the meantime I do not wait for that day, meaning this letter to stand for the first in the series. But now it occurs to me (on the moment) that we should so arrange that one should write after receiving the letter of the other - say that I write on Saturday or Friday and you on Sunday.

I am greatly pleased indeed to hear of your augmentation. I daresay the war has something to do with it - although the improvement is not general in London as far as I can hear. Guy's is said to be good this year, but the reports of most other schools is [sic] different.

We had our Anniversary at the R[oyal]. S[ociety]. on Friday - things went off pleasantly notwithstanding a speech from (the eternal) Mr. Babbage ${ }^{1}$ not blaming the Council but lamenting or affecting to lament that we had not given the Copley Medal to Mr. Schentz the Constructor of the Surdish Calculating Machine. His allusions to his own achievement in this way were in a very moderate tone. But it was curious to see how the consciousness of his own merit peeped out - in short it was one word for Schentz and two for himself. We had a very pleasant dinner afterwards at the Free Masons Tavern at which Sabine ${ }^{2} \&$ I ingeniously contrived to make Graham propose the President's health, by threatening in case of refusal to give "Her Majesty's Government and the Master of the Mint". ${ }^{3}$ We had a table a stupendous Jack (or Pike) three foot \& a half long sent by Mr. Whitbread the Brewer who is a fair Amateur Astronomer \& is getting a noble Lens ground for his new Telescope - I told him afterwards that some friends (Paget ${ }^{4} \&$ Burke) who sat near me regretted it was not made into a Skeleton, but indeed we left nothing but the bones.

I have just received Bennett's Introductory Lecture for the past Session ${ }^{5}$ - on glancing through it very rapidly I was rather pleased on the whole. Will the great Lay-Cock print his first crow? I quite agree with you that people must suspend their judgment as to his success, till better assured one way or the other - and with our friend Syme indifference would take the shape of absolute failure - An intelligent student of ours now a resident in the Edin. Infirmary, who came here the other day to take his Degree of M.D. spoke as if the reports of the new man inclined to be unfavourable - that he laid little stress on Auscultation or Microscopic research. My young friend had been Clinical Assistant to Christison \& to Bennett.

Having given you the above sample of gossiping - such gossiping as may make the staple of my correspondence, turn now to a little point of business lest I should have to entamer a third sheet. I wish to know confidentially what kind of person you think Dr. Harley ${ }^{6}$ who was once one of your Pupils - and I think an Assistant to Simpson - \& 
who has since been studying under Bernard, Robin \& Verdril - Kölliker, Scherer \& Virchow? He has applied to be teacher of Histology \& Practical Physiology in our College - and as the Assistant Curatorship of the Museum happens to be vacant he is now filling that post temporarily.

The case of the Mylnes if not uncommon - two members of a family cut off within a short time of each other - 'Tis almost a wonder James Mylne did not fall before now - considering his infirm health and the way he guided it. I had agreeable news of your Sister through Miss Graham - who on her way to Rome passed a short time at Nice \& is loud in praise of Mrs. Mylne's attention and Kindness.

The little packet was from Retzius - containing injections of biliary ducts, which he wishes me to show to Kiernan. ${ }^{7}$

With kind regards to Mrs. T. \& family - Your sincere friend

W Sharpey

\footnotetext{
${ }^{1}$ Charles Babbage (1792-1871), mathematician and inventor of an early form of computer.

${ }^{2}$ Edward Sabine (1788-1883), soldier and natural philosopher, was himself elected President of the Royal Society in 1861 .

${ }^{3}$ Graham was appointed Master of the Mint in 1855.

4 James Paget (1814-99), Assistant Surgeon at St Bartholomew's Hospital, had been a Fellow of the Royal Society since 1843 .

5 John Hughes Bennett, The present state of the theory and practice of medicine, Edinburgh, Sutherland and Knox, 1855.

${ }^{6}$ George Harley (1829-96) graduated MD at Edinburgh in 1850. He secured the demonstratorship in histology to which Sharpey refers.

${ }^{7}$ Francis Kiernan (1800-74), examiner in anatomy at the University of London. He was the author of The anatomy and physiology of the liver, London, R. Taylor, 1833.
}

\section{6}

Boils

College, Glasgow

9th Dec./55 Addressed to 33 Woburn Place

My dear Sharpey,

I was very much gratified by receiving so promptly a letter from you, and I cannot do less than reply on this appointed day, though I cannot expect to give my epistles that amount of interest which I may count upon from those coming from the metropolis.

It is very annoying indeed that you are still troubled with the boils. What do you say to a trial of the panacea Cod liver oil. ${ }^{1}$ I have very great confidence in its changing just such conditions of the system as that under which you are suffering.

Begin with small doses such as a tea spoonful at a time, and I believe a little dry oat meal after it is the best thing to put away the taste and oily feeling in the mouth.

It was indeed a shame to eat such a magnificent pike as you consumed to the backbone. I am in expectation of some fishes from the Mediterranean, through Verany at Nice with whom John Mylne and my sister are acquainted. There are some Torpedoes, Chimeras and Young Sharks from the Uterus, I hope with external gills. 


\section{Letter 56}

My friend has not come back yet from Western Africa, but he writes that he has been very unsuccessful, having only procured one chimpanzee. I have got from a pupil who was in the North last summer specimens of the Clio borealis, and another interesting Pteropode the Limacina which is coiled, and has a small rudimentary shell on one side. I was interested by obtaining just at the same time a specimen of the only Pteropode found in the fossil state, and that not very common, viz. Conularia quadrisulcata from the limestone shales between the upper and lower coal beds of this district.

We have just had a visit of John Mylne and I daresay you may see him ere long on his passage through London on his return to Nice. He tells me that his brother James has left his family very wealthy. He has given me as a rememberance of his brother William a very nice copy of the reduced edition (Roy. 8vo) of Audubon's American Birds. ${ }^{2}$ It seems to exhaust the subject completely and also is a most elegant drawing room book.

We had an interesting meeting or soiree of the Athenaeum on friday evening at which there were some good addresses. The speech of James Moncreiff ${ }^{3}$ the Lord Advocate pleased me extremely. His theme was the education of the people and his sentiments were of the most liberal kind. Notwithstanding his being trammelled somewhat by the free kirk[.] I think I can see that he has had enough of kirk difficulties in connection with the education question and that he will be disposed to act more independently when next he brings the subject before parliament.

My number has closed at 170 in all. 155 in one class \& 135 in the other. I am introducing more examination than I used to do for I become more \& more convinced of its importance in elementary instruction.

I am actually bringing ovum to a close. I expect to have it out of hand by the New Year, and I hope I will not run my neck into such a noose again. After all it will be a failure as I have missed the mark: but I shall be so happy to be done with it that I shall scarcely mind its success.

There has fallen into my hands a beautiful book by Rusconi which I had not seen before viz. On the development of the Land Salamander published posthumously[.] ${ }^{4}$ The plates are exquisite. There is also a Memoir on the fecundation (artificial) of fishes and the development of fishes published like the other in 1854 by Moyanti and a biographical account of Rusconi by Serafino Biffi. They were sent to the Brit. Ass. and the local Committee paid £6-6 for the carriage; but I mean to have them for our library or myself, so you need say nothing about them, in case any body having less right to them than myself should ask for them.

I am rather annoyed to find that I cannot from my recollection at this moment give a distinct account of Dr. Harley about whom you inquire. In 1847-8 I had a George Harley a good student but I cannot recover his face or his qualifications, the more so that there was also a student of the name of Hartley the same year. If I saw him or had any circumstances to awaken my reminiscences I might be able to say more.

But I must conclude I send you a note about my philos. trans. $\mathrm{w}^{h}$ I am ashamed to have neglected so long.

Ever Dear Sharpey most sincerely yours

Allen Thomson 


\section{Letter 57}

\footnotetext{
' Probably an allusion to John Hughes Bennett, Treatise on the oleum jecoris aselli, or cod liver oil, as a therapeutic agent in certain forms of gout, rheumatism, and scrofula, Edinburgh, Maclachlan Stewart, 1848.

2 John James Audubon, The birds of America, from drawings made in the United States and their territories, New York, J. J. Audubon, 1840-4.

${ }^{3}$ James Moncreiff (1811-95) succeeded Andrew Rutherfurd as Lord Advocate in 1851. In February 1854 he introduced an Education Bill for Scotland, which was rejected in Parliament. A second Bill in 1855 was passed by the Commons, but thrown out by the Lords.

${ }^{4}$ Mauro Rusconi, Histoire naturelle, développement et métamorphose de la salamandre terrestre, Pavia, Bizzoni, 1854.
}

\section{7}

Wrote 29th [This is in Thomson's hand]

33 Woburn Place, London (W.C)

14th March 1857

My dear Thomson

I heard of Johnny's having had Scarlet Fever after he had passed through the danger, but I was not aware that he caught measles afterwards - It is well he is rid of both. I have a horror when I hear of epidemic scarlatina - not on my own acccount indeed for I am proof against fevers of all kinds - but I know of no disease as suddenly \& widely diastrous when it gets into particular families.

I am glad to hear such good accounts of your class and of your new modifications of your Lectures - No doubt the more the Student is made an active rather than a passive participator in a course of instruction so much the better. I heard good accounts of your Edin. Lectures ${ }^{1}$ - and there is much new matter as to the eye which I will be glad to learn from you - when we meet. Since I saw you I have gone somewhat into the question as to the nonstriated muscular tissue - \& I am satisfied Ellis ${ }^{2}$ must give up the point. The "weeny ovum" is very welcome -

But my main object in writing you at this moment - and my reason for not entering into scientific affairs - is to remind you of your intention \& promise to pay us a visit at the end of the session - in company with $\mathbf{M}^{r s}$ Allen. Try and finish as early as you can so that you may have longer time to be here - and as we shall be delighted if you bring Johnny with you - Let you and your worthy spouse sit down and settle at once the time of your coming \& let us know \& if there is anything I can do to further any purpose you may wish to fulfil in London besides friendship - I will be most happy to set about it -

I am truly sorry to hear your account of Ninian [Hill] - but it is consolatory to think that complaints like his are not now viewed so despairingly by medical men as formerly - How happy to be able to choose Nice where of course he would be kindly tended.

Political people, as you know, are at present in a hubbub - Finsbury is one of the largest constituencies in the kingdom if not the largest $\&$ what an atom I feel myself to be in such a mob - Time was when I should have gone to hear the candidates - but now I care little for these things - and have little faith in public men - as such. Every body cries out in admiration of Lord Palmerston's good luck - whatever may be thought of the China business ${ }^{3}$ - He must have dissolved at the end of the 


\section{Letter 58}

Session - with some objectionable points for his opponents to harp on at the hustings - but the Derbyites \&c. have stepped in to send him to the country on a question in which he will doubtless be popular - i.e. backing up his agents and boldly taking responsibility. No doubt the China affair is an unlucky business \& God knows when it will be settled - but to disavow the proceedings of our People then would not have mended things. Your young Laird (of Hatton) is a Candidate for the Fellowship of the RS. this year - Sir Roderick ${ }^{4}$ speaks most favourably of him - indeed every one I have heard who knows him - Remembering your skill in arranging our old house - how happy I should have been had we had the benefit of your aid in our arrangements in Burlington House. ${ }^{5}$ We are getting the books fast in - and busy rearranging them - but we shall not be able to use the new hall for our meetings for some time yet.

With sincere regards to Mrs Allen

Dr Allen Thomson

$$
\begin{gathered}
\text { Believe me } \\
\text { My dear Thomson } \\
\text { Yours most sincerely } \\
\text { W Sharpey }
\end{gathered}
$$

\footnotetext{
${ }^{1}$ Possibly a reference to Allen Thomson, 'On the phenomena and mechanism of the focal adjustment of the eye to distinct vision at different distances', Glasg. med. J., 1858, 5: 50-69.

2 Ellis advanced a heterodox theory of the structure of involuntary muscular tissue, arguing that it was fundamentally similar to that of voluntary muscle. See G. Viner Ellis, 'Researches into the nature of the involuntary muscular fibre', Proc. $R$. Soc. Lond., 1856-7, 8: 212-3; idem, 'An account of the arrangement of the muscular substance in the urinary and certain of the generative organs of the human body', Med.-Chirurg. Soc. Trans., 1856, 39: 327-38.

${ }^{3}$ In March 1857 a general election was called after the government was defeated on a parliamentary motion calling for an investigation into the outbreak of war with China.

${ }^{4}$ Roderick Impey Murchison (1792-1871), geologist, had been a Fellow of the Royal Society since 1826.

${ }^{5}$ Burlington House was the new premises of the Royal Society.
}

\section{8}

10th July 1857
By the bye. I have never received any of my photographs. Should I write directly to the Artists did you order the six which I wrote to you about?

Hatton House, Ratho

My dear Sharpey,

As I have the expectation of seeing you soon I will not enter upon a long letter, but only write to make inquiry as to the time you expect to be free and to come down to see us. The weather has been a little changeable, but on the whole fine and occasionally very much so, and you will be quite charmed with our beauties if you come in the proper season. I trust therefore to your holding to your intention of getting down in July to see things when they are at their best. I may add that both the ducks $\&$ green peas are in a prime state. 
I have not been very well for the last week having had a bilious attack brought on I believe by some indiscretions in diet conjoined with the irregularity $\mathrm{w}^{h}$ is apt to be produced by my frequent journeys to Glasgow; but I am getting out of it and hope to be quite equal to walks with you.

My course has done pretty well, at least I have great reason to be flattered with the attendance having had upwards of 100 students and occasionally as many as five professors. It has not given myself great satisfaction, the nervous system as a whole being far too extensive a subject to study in three months and that study being continually interrupted by the necessity of giving expositions of what is known and of providing illustrations.

Tuesday and thursday are my regular days of going to Glasgow: and I sometimes go on a Monday when required, but if I choose I can spend from friday to tuesday quietly here - I shall lecture for 2 weeks more. Now write me a note as soon as you can \& tell me your plans.

I am quite out of the Medical world so I am far behind as to what is doing or to be attempted by the Universities in the Medical Bill ${ }^{1}$ being in Committee. I always feared that the influence of the Corporations $w^{d}$. be sufficient to carry their measure.

I have a printed Circular in reference to a proposal to modify the division of the University faculties especially that connected with "Science" as they call it by which I presume they mean Natural or physical science. I quite approve of some such modification as that pointed at in the Circular. viz. that physical science should have two main divisions. A physico-chemical and another comprehending Natural history $\&$ Biology for $\mathrm{w}^{h}$ a convenient name would be desirable. If you have time would you give me a hint whether it is proper for me to reply \& give my opinion and what are your views.

I must not delay longer - but hoping to hear from you soon I am ever sincerely yours Allen Thomson

\footnotetext{
${ }^{1}$ A reference to the Bill which became the Medical Reform Act of 1858. This measure made provision for the registration of all qualified practitioners and created a General Medical Council on which the universities and medical corporations were represented.
}

\section{9}

33 Woburn Place, London

15 November 1857

My dear Thomson

I ought to have replied to your letter before this but something came in the way at the time to make me defer it.

The piece of microscope was left by Kölliker (as he did not go home by Paris) to be taken charge of by Ninian. Mary carefully put it out in order that it might not be forgotten but the Servant, thinking it was something out of its place, put it back into the drawer \& so it was left behind. I have already spoken to one or two people who have much intercourse with Paris, to let me know when an opportunity offers - and 
although none has occurred as yet, still I think we shall more readily find the means of sending it from here than you are likely to meet with at Glasgow - and I shall not neglect it.

Roper has not turned up yet. I find some of the English Geologists speak rather harshly of him - but his reputation is such - with Scientific men in general, that there would be no question as to his being one of the fifteen selected for the RS.

I am glad to hear that the "Laird" is to make his appearance at Burlington House on Thursday. I will not neglect to indoctrinate him properly as to Hatton - if the opportunity should offer.

I am sorry indeed for the hard fate of bona fide mercantile Houses in Glasgow as elsewhere - but I find the common reproach of trading on other people's money is especially applicable to your neighbours. I am concerned to hear of the loss which the Mylnes will sustain - and I am sorry to say that Dr. Arrott who is much less able to bear loss - has one or two shares in that abominable Western Bank. ${ }^{1}$ I warned him years ago not to trust to these people - but a "wilful man" as they say \&c. -

Dr. Livingstone ${ }^{2}$ told me that he had once given a supply of the poison used by the Bushmen in South Africa for their arrows - to Dr. Buchanan ${ }^{3}$ - Would you ask Dr. B. for some of it? for Koelliker \& a little for me. Koelliker has been experimenting with the Upas Antiar. \& Tiliste (Tchetick) \& proposes to send a communication to the R. S. on the subject - I have been making one or two trials (rather in a desultory way) with Mr. Antiar. Brodie, long ago \& found that it stops the heart as Koelliker finds at [. . . ] - I find that it extinguishes the irritability of the muscles generally - Koelliker who I suppose has worked out the phenomena thoroughly, writes me the same thing - but it appears to me that the motor nerves lose their excitability also - I have been studying Koelliker's Memoir on Poisons ${ }^{4}$ - which is quite a masterpiece - \& I have repeated some of his expts. with the Woorrara[?] - very satisfactorily. Koelliker got some of the Antiar \& the Tchetick from old Dr. Horsfield who was long in Java \& wrote a memoir on these poisons more than forty nearer fifty years $\mathrm{ago}^{5}-$ I have since called on the old man and obtained a further supply of Antiar for Koelliker (and myself) and I will be happy to give you a little if you should want it. It was examined chemically long ago by Pelletier \& Caventou - \& more recently by Muller, ${ }^{6}$ but I hope Koelliker will find some competent man at Wurzburg to give it a further scrutiny.

My Class is not so good as in 1855 - but rather better (in new Entries - "Gulpins as ye may call 'em" Lizars.) than last year. Aitken called today - his book ${ }^{7}$ will be out in a few days - I presume that Watson's Lectures will keep their ground but there is nevertheless quite room for another.

Mary sends her kindest regards to you-Mrs. Allen \& Johnny. Heartily joining therein I remain

Dr. Allen Thomson

\section{Yours very sincerely}

W. Sharpey

\footnotetext{
${ }^{1}$ A Glasgow-based bank which went into liquidation.

2 David Livingstone (1813-73), medical missionary, I presume.
} 


\section{Letter 60}

\footnotetext{
${ }^{3}$ Probably Andrew Buchanan (1798-1882), Professor of the Institutes of Medicine at Glasgow University.

${ }^{4}$ Presumably Albrecht von Kölliker, 'Observations on the poison of the Upas Antiar', Proc. R. Soc. Lond., 1857-9, 9: 72-6.

${ }^{5}$ Thomas Horsfield, 'On the Oopas or poison-tree of Java', Ann. Philosophy, 1817, 9: 202-14.

${ }^{6}$ Joseph Pelletier and J. B. Caventou, 'Examen chimique des Upas', Annls Chim. Phys., 1824, 26: 44-63. I have not traced the Müller article.

${ }^{7}$ William Aitken, Handbook of the science and practice of medicine, London, Griffin, 1858.
}

\section{0}

Wrote $31^{\text {st }} \operatorname{Jan}^{\text {y. }}$ [This is in Thomson's hand.]

33 Woburn Place, London W.C

21st Nov. 1857

My dear Thomson

We had a very good opening Meeting at Burlington House on Thursday evening. Your young Laird was there $\&$ we were introduced to each other by Sir Roderick, who stood father to him on his admission. We had a very short talk together partly of Hatton - He is satisfied that it yet wants much clearing \& he intends paying a visit himself bye \& bye \& setting about clearing, seriously and on a plan. He would be much improved I think by clearing away his moustache which is broad short \& scrubby - something like the brushwood at the west end of Hatton House.

I and Mary are sincerely happy to hear so good accounts of the travellers. It was a very pleasant time for us - the two days they were here - \& I need hardly say that we look forward to a repetition of the pleasure when they return. - I was anxious about their success in a lodging - \& am right glad to hear that they have got all they want without paying what in Scotland we call a heavy "ransom".

I wish the benefit of your contriving skill, to advise me how best to make a plan for keeping \& rearing rabbits. They are dearer than dogs in London and the high price really stands in the way of employing them for experiments. There is a large piece of waste garden ground at the College pretty well out of sight, so that a rabbit hutch would be no eyesore - Make me a plan of one \& I will laud you. I wish also to try and keep frogs. We can easily direct a streamlet from our water pipe into a tank for the purpose - How should a tank be made? What would be requisite to prevent the creatures from escaping? Had we a proper place I should try and breed the rana esculenta which is much larger than our frog - It would not be difficult to get a stock from the continent - I have suggested to Lister that his Father's place at Upton would be well suited for such a trial. But I don't see why we might not make it answer at the College.

Yours ever $\operatorname{sinc}{ }^{y}$.

W. Sharpey

Dr. Allen Thomson 
61

Hatton House, Ratho

10th Augt. 1858

My dear Sharpey,

I was very glad to hear something of you though indirectly through our travellers. I daresay you will have enjoyed your visit to Koelliker much.

I dined with the Symes yesterday and they like us are desirous to know your Autumn movements and are looking forward to the pleasure of seeing you. I was greatly shocked as you may believe with poor Mr. McVicar's appearance. I saw him only for a minute reclining on a sofa in the upper parlour pale \& emaciated and with all the look of a person dying rapidly from Organic disease. I did not get any statement from Syme of the nature of his disease, but I believe it is some tumour either of the stomach or liver. His appetite seems to be nearly gone and I do not think he can live long. There can be little doubt that his misfortunes have hastened very much if they have not altogether caused this sad change. What a comfort it must be to Mrs. McVicar to have all the kindness and attention they receive at Millbank.

Your absence from London prevented me from writing to you on a matter on which I would now wish your advice and if possible your assistance. The second son of my late Colleague Dr. John Couper (bearing the same name with his father) ${ }^{1}$ has been a very promising pupil of our school, and having been left some fortune \& not having any liking for Medical practice, would fain set up somewhere as an Anatomical or physiological teacher. I have explained to him that a thorough acquaintance with the drudgery of the dissecting room is the first thing he must have to make himself an anatomical teacher, and he is quite prepared to go through it. He would prefer greatly to be in London and I have promised to inquire for him through [you] or Mr. Ellis whether it might be possible for him to get a position in your school as an under demonstrator or something of this kind which would introduce him to the practical knowledge of Anatomical teaching. He is a very sensible quiet laborious young man a very good dissector, has been on the continent for some time, has taken his degree in Glasgow, and is now anxious to set himself up in some employment and means to proceed to London about the 18 th or 20th of this month when his engagement as Clerk in the infirmary comes to a close. I will give him an introduction to you and I shall take it kind if you have any thing encouraging to say if you will write me here before the 16th when I expect [him?] to come to Hatton to pay us a short visit, and pray let us know when we may expect you down.

I have a great deal to say to you about University \& Medical Bills and other matters, but I dare not venture to begin them at present. All here join in kindest regards and I am ever

Most sincerely yours

Allen Thomson

\footnotetext{
${ }^{1}$ John Couper, graduated MD at Glasgow in 1858, was sometime Professor of Physiology and Anatomy at the London Hospital Medical School, and later Lecturer on Surgery there.
} 
62

University of London Examin ${ }^{\text {n. }}$

12th August $1858-3$ p.m.

My dear Thomson,

Here I am in a very very hot \& close afternoon looking after a set of men at an Examination. I foresee that the looking over their papers will last until Wednesday night or thereabouts.

I have spoken to Ellis about young Couper. It is unlucky that Ellis has already arranged not only with a gentleman to be his regular Demonstrator but also for another to be a sort of Supernumerary. I do not think Mr. Couper would have much or any difficulty in obtaining an appointment at some of the Smaller Schools - but then I don't think that would answer his purpose. A Lectureship even in a small School would (were he ready for it) give him the opportunity of trying his hand at the work \& furnishing evidence of capability when something better should turn up - but a Demonstratorship would be of little use - Should he come to London, I will give him a note to some of the Anatomical Teachers in the principal Schools \& mention his object - but I presume that their arrangements are already made for next Winter. After all, unless he has some other objective in coming to London now - I think he would prepare himself to be a teacher of Practical Anatomy much better by undertaking to work under you at Glasgow this winter as ass ${ }^{t}$. Demonstrator. I am satisfied that the work is much better and more methodically conducted at your own School than it is any where in London - This I say as a matter of business \& without any nonsensical flattery - and I verily believe Mr. Couper's best plan would be to "bury" himself (as your Father once said to me) in your dissecting room \& work constantly and very hard at pure anatomy - I did this in Berlin in the winter of 1828-29 - and I may say that from daylight till 12 p.m. every day Sundays - even Christmas day not excepted I carried the work on. It is the only way to learn thoroughly the whole matter of descriptive anatomy-\& with you he would have the advantage of learning methodically the art of supervision of Students - I may add that I think it is a defect of several modern Physiologists that they are not sufficiently grounded in rough anatomy - It is a most valuable foundation \& specially necessary for the study of comparative anatomy -

I scarcely remember an event which has caused me more concern \& excited more sympathy than what has happened to McVicar - I do believe that his loss of fortune distressed him quite as much on account of others as of himself - \& I doubt not that had his health not given way he might have soon reconciled himself to his altered circumstances, which would still have allowed him to live at ease tho' not in affluence - but from what you tell me \& what I have heard from Lister who is with his friends at Upton just now - I fear he must be rapidly approaching his end. Few will be more lamented.

I hope to see you before October - probably about the end of this month - but I should like to know whether one time would be as convenient for you as another for my visit to Hatton - I doubt if it would be suitable for me to go to stay at Millbank while there is so much cause of affliction there - I will write you again shortly - 


\title{
Letter 63
}

I have a good deal to tell you about our visit to Germany - which was really very agreeable - I was very loth to move from home - but once the inertia was overcome - I was delighted with the motion - my only regret is that we missed the Roman travellers as they passed thro' London -

I see I have filled two sheets - I will therefore reserve the remainder (as the Ministers say) for another occasion -

\author{
Yours very sincerely \\ W. Sharpey
}

63

Private

The College, Glasgow

26th November 1859

My dear Sharpey,

It is I must say a great grievance that the appointments to scientific chairs in the Universities should be influenced in the manner which it appears is being done by the Glasgow Members in the case of the Surgery Chair. ${ }^{1}$

I understand that through Dr. A. Buchanan's friendship for Dr. Lawrie, his brother Walter Buchanan ${ }^{2}$ espouses warmly George McLeod's ${ }^{3}$ interests, and that through private friendship with old Dr. McLeod ${ }^{4}$ (who is his neighbour in the country) Mr. Dalgleish has with equal warmth taken up the Cause of his son; and that thus these two sapient radicals have taken up the cause of the Candidate of the greatest \& most unscrupulous tory connection in Glasgow on the grounds of private friendship and the flimsy \& absurd view that Surgeons of Glasgow growth should alone obtain places in its University "Our own fish guts \&c."

I really trust that Sir C. Lewis ${ }^{5}$ will see through this kind of thing, and I am sure that if he consults such men as Sir James Clark, Sir Ben ${ }^{n}$ Brodie and the like, he will have the grounds on which such an appointment is to rest placed in a very different light. I would not wonder but that it may be represented that the University professors are chiefly in favour of George McLeod: but this is entirely false. Indeed when poor Lawrie proposed him as his substitute, we were very averse to take him, partly because some thought him by no means the best person, and partly, because with Dr. Lawrie's own concurrence he had been secretly engaged in a canvass for the chair as if it had been vacant: and Dr. Lawrie's Colleagues went the length of offering among them to conduct the course for him. Dr. Lawrie declined this offer and pressed Dr. McLeod on the Senate, who could then do nothing else but sanction his appointment as substitute: but in order to protect ourselves from any appearance of expressing preference we put upon the Minutes the following: "The Senate in deference to the wishes of Dr. Lawrie accede to his request and hereby authorise Dr. G. McLeod to act as assistant to Dr. Lawrie during the present session. At the same time in consequence of the circumstance that from some error or misapprehension a canvass for the chair of Surgery has been commenced and prosecuted as if the chair were actually vacant, the Senate think it right to add that in sanctioning the appointment of Dr. G. McLeod they do not mean 
to express any opinion with regard to his professional qualifications as compared with those of the gentlemen who have announced themselves as candidates." This was as strong as could be in the circumstances. It would have been equally improper for us to have done anything directly to prejudice McLeods claims: but we felt that he was to be under great advantage in being named Lawrie's substitute.

I do hope that Lister's claims may have a fair judgment. I need scarcely say to you that I think him out of all sight the best man, \& how much I should rejoice if he can be secured for our University. But testimonials are now so absurdly got up, that it must be difficult if not impossible for a person ignorant of the character of the writers to appreciate their true value. - When I lately saw Sir John Herschell's ${ }^{6}$ and De Morgan's testimonials for Grant ${ }^{7}$ in the Astronomy Chair I knew \& said at once, that is the Man, for I knew that neither of those would write such testimonials without good reason; but among the herd who gives testimonials for Surgery chairs two thirds would require explanatory notes or testimonials to inform us who the writers themselves are, and the value of the testimonials is now almost in the inverse ratio of the strength of expression of praise in it. It is necessary therefore that men whose opinions may be relied on should assist Sir C. Lewis in his judgment and I hope there will be ways of bringing this about. I have of course like the rest of my Colleagues the deepest interest in securing the best man: and it seems very strange that parties who have no real interest in the University should be permitted to interfere upon false grounds and warp the judgment of those in authority. It is hard to say how much of political chicanerie there may be under the semblance of liberality in what is going on here. Neither of our members are very secure in their seats and I can easily imagine that they will be glad to find means to keep quiet at least a portion of their tory opponents.

I have made it a rule as much as possible to abstain from interfering in connection with appointments to our own University and I have therefore refused testimonials to all the Candidates who applied to me. I am very unwilling that my name should be used in any way connected with the Canvass: but, I think it only justice that the course of circumstances here should be rightly known and I hope you may have some opportunity of farthering the best appointment for us.

I am ever Dear Sharpey

most sincerely yours

Allen Thomson

\footnotetext{
${ }^{1}$ In November 1859 the Surgery Chair at Glasgow became vacant as a result of the death of James Adair Lawrie.

${ }^{2}$ Walter Buchanan (1797-1883) and Robert Dalglish (1808-90) were the two MPs for Glasgow in 1859. Dalglish, in particular, was noted for his Radical views.

${ }^{3}$ George Husband Baird Macleod (1828-92), Glasgow surgeon. He became Professor of Surgery at the Andersonian College in 1859, and eventually succeeded to the University Surgery Chair in 1869.

${ }^{4}$ Norman Macleod (1812-72), noted preacher and father of G. H. B. Macleod. He was Minister for the Barony Parish in Glasgow.

${ }^{5}$ George Cornewall Lewis (1806-63), Home Secretary in Palmerston's government.

6 John Frederick Herschel (1792-1871), astronomer and natural philosopher.

${ }^{7}$ Robert Grant (1814-92) was appointed Professor of Practical Astronomy at Glasgow in 1859.
} 
64

The College, Glasgow, 27th November 1859

My dear Sharpey

Though I would gladly have kept out of direct interference in the Surgical Canvass I feel it of such importance and that Lister's qualifications are so superior that I have forced myself to it and have written to Lord John ${ }^{1}$ such a letter as I think if he is disposed to use it will do some good with Sir C. Lewis. I enclose a letter to yourself which of course you will regard as private: but you will observe it is written in such a manner that if you see it can be of any use with any influential persons to whom you have access you may privately employ it in the Cause. I have also written to Benj ${ }^{n}$ Bell $^{2}$ in Edinburgh a letter the same purport, which $I$ have some expectations he may shew to the $\mathrm{L}^{d}$ Advocate.

They are all different a little but touch upon the interference of the Glasgow members, which I hope may set up the jealousy of the men in power. I fear the effect might not be great were parliament meeting, but in the recess we may hope for something.

I must take another time to write you on other matters as I have been intending for some time. I have a larger class by 25 than last year \& am very busy.

Ever sincerely yours

Allen Thomson

${ }^{1}$ Russell was Foreign Secretary in Palmerston's government.

2 Benjamin Bell (d. 1883), Edinburgh surgeon.

\section{5}

Edinburgh

$2^{\text {nd }} \mathrm{Jan}^{\mathrm{y}} 1860$

My dear Sharpey,

I find Lister's election stands just as I was supposing. There is a hitch at head quarters in consequence of the pressure of the Members for Glasgow. Lister has both the Lord Advocate and the Home Secretary in his favour, and yet the latter is so pressed upon by the Glasgow people (Members chiefly I suppose) that he refrains from making the appointment.

I learned last night that a reference has been made to the Glasgow Members. Dr. Cowan ${ }^{1}$ was the authority and I think it very likely that he had it from Mr. Dalgleish the Member himself, so there is some truth in the report, though the terms in which the reference has been made may (as I hope they are) be exaggerated. I have got the same information this morning from a reliable source. It is very unfair to the $\mathrm{L}^{d}$ Advocate and to us also. But I hope something may yet be done to neutralise the influence. Of all things the best would be a reference to Brodie whose clearness and decision would confirm Sir C. Lewis in his selection of Lister and make him complete the appointment at once. 
As the bad news kept me awake I penned this morning the arguments as they occurred to me on the accompanying papers in a letter to you, in case you may have it in your power to do any thing. I have seen Syme and we do not know of any other or better channel than through Sir James Clark and I would hope that through him or otherwise you could get a reference to Brodie made.

Of course after the scrapes I have already got in to I should like to keep out of view. I am aware too that my letter is a dreadful long rigmarole: but it contains arguments which if properly condensed might I think weigh with Sir George Lewis. Poor Lister who was feeling somewhat sure of success will be dreadfully disappointed and I shall not be less so if we fail.

Pray write me soon and believe me ever yours

Allen Thomson

You will understand that the subject of a difference between the $\mathrm{L}^{d}$ Advocate and the Home Secretary or the fact that the latter has not acted on the Advocate's recommendation must be kept to yourself. I have it quite confidentially -

We return to Glasgow tomorrow morning[.]

Johnny is rather better.

\footnotetext{
1 John Black Cowan (1829-96), lecturer in medical jurisprudence at Anderson's College and Assistant Editor of the Glasgow Medical Journal.
}

\section{6}

The College, Glasgow ${ }^{1}$

2nd $\mathrm{Jan}^{y}, 1860$

Private

My dear Sharpey,

Since I last wrote you I have learned that it is asserted in Glasgow that Sir George C. Lewis has consulted or deferred to the Members of Parl ${ }^{t}$ for the City for a decision or advice as to the fittest person to be appointed to the Chair of Surgery in the University. I still indulge a hope that this statement may not be correct or at least may be exaggerated: but as it came to me through a source from which I thought I could trace it to one of the members himself, I feel extremely anxious as to the result of the nomination to this chair. I have always heard Sir G. C. Lewis spoken of as a man of so much independence of thought and action, and of such scrupulous fairness, that I think it is possibly from the very love of justice that he has been led to adopt this plan of endeavouring to remove the doubts from his own mind, imagining that he will thus obtain a fair exposition of public sentiment upon the subject: Or it is as likely that he may have been pressed upon by the Glasgow members themselves to adopt this course by their representation that the Glasgow public have decided views upon the subject. This I believe to be altogether groundless and can only be brought forward for party purposes. We already know well how much parliamentary influence may be brought to 


\section{Letter 66}

bear on questions of this kind with which it ought to have no connection. It is most desirable for the sake of the University of Glasgow in relation to the present appointment, and in the interest of the Scottish Universities in general that a representation should be made to Sir George Lewis which might place this matter in its true light and remove from his mind the idea that the views advocated by the members are those of the community at large, or such as deserve any attention in connection with the interests of the University - Perhaps you will be able to advise us as to the manner in which such a representation could best be made to reach Sir George Lewis.

The question itself seems a very simple one. The University and the public wish to obtain the fittest and most eminent man to fill the chair, the person who will best discharge the immediate duties of a public teacher, who is best fitted by his character, conduct and manners to maintain the influence and dignity of the professorial office, and who by his ability, laborious research and scientific spirit and capacity has the greatest power to spread sound views and to extend the boundaries of Surgical science. $W e$ know quite well that Lister is the only man in the field who possesses all these qualifications combined and we know that he possesses them in a high and unusual degree. So certain are we indeed from our means of knowledge of his superiority that we are surprised that others are in any doubt as to the selection of the best candidate. But when we look to the testimonials (those dreadful deceits of modern times) and to the secondary influences which are habitually brought to bear upon patrons on such occasions, it must be confessed that it is not wonderful that in a matter where it is almost impossible for them to form any direct opinion for themselves, they should be involved in perplexity -

How then is that perplexity to be removed, or how may the patrons judgment be assisted? [S] urely by a reference to persons who are known to be capable of forming a judgment and to those parties who have the deepest interest in the excellence of the appointment. The Scottish University Act $^{2}$ seems to me to point distinctly to a solution of this difficulty which will be available hereafter if not at present, in the establishment of the University Court which is so constituted as to represent in an impartial manner all the University interests, and which indeed is now vested with the patronage formerly in the hands of the Senatus. A reference to this Court would be a simple and fair thing in such a case as the present. Perhaps it might be said that the University Court is not yet fully established, nor ready at this moment to respond to such a reference. If so, there is another course equally good, and perhaps simpler, and one which on public grounds may be considered as most eligible. I mean a reference, in the case of a Medical chair to one or more of the General Medical Council. Sir Benjamin Brodie as the first Surgeon of the day and President of the Council, and Sir James Clark as one of the Government Nominees in the Council and well acquainted with the system of medical education pursued in the Scottish Universities, are both of them men whose opinion would carry the greatest weight with the public, and who would give that opinion solely on the ground of the qualification of the candidates.

Why the Members of Parliament for the City should be consulted in preference to such men as these I am at a loss to comprehend. It could only be upon the plea that they are supposed to represent the opinions or wishes of the citizens of Glasgow and may have more reliable sources of information not accessible to other persons. A Member of Parliament is not a better judge of the fitness of professors of Surgery than other 
men. He is liable to be influenced by one or other political party or section of the Community, according to the manner in which he may have been returned. He is liable to influence those in power according to his own party bias. He has no special connection with the University which entitles him to be selected as adviser in relation to its affairs. A special member for the University would have had a title to be consulted in such a case: but if Parliament had thought the City members entitled to such reference, it would certainly have accorded some official position to those members in the University Court or Governing Body by the recent Act.

[T]here is no medical professor in the University (with the exception perhaps of Dr. Buchanan who early committed himself to the support of Dr. McLeod) who would not repudiate such a principle of selection with scorn and ridicule, and who would not declare that the fittest man should be chosen from [sic] the chair, quite irrespective of all local partialities or party influence.

I have no desire to detract from the merits of any of the Candidates in what I say: but I wish earnestly that means could be taken by patrons of a satisfactory kind to ascertain, not what are the wishes of this or that influential individual or class of the Community, but rather which of the Candidates really possesses the greatest amount of those varied qualifications which make a man an efficient teacher, a dignified professor, and give him eminence and distinction in the scientific department of his profession. I wish Sir G. C. Lewis could know and appreciate how anxious we are to have the best appointment made for the sake of the University and its Medical School. And if he could fully understand this I would not wonder at his then consulting the Senatus (that much suspected body) who have some title to offer an opinion upon the selection of a professor, rather than individuals whose position may give them influence and power, but who have not otherwise more means of forming a just opinion upon this matter than any private member of the Community of Glasgow.

I am satisfied that it can only be from a misrepresentation of the state of public opinion in Glasgow upon this matter that a reference to the Members for the City has been urged - But it is obvious that this may be a mere clamour in which a number have combined to serve a diversity of individual claims - in the same manner as the manifesto from a number of the medical profession. The citizens and the University will I am persuaded accept cordially and at once any good appointment that is made, and the profession, if the majority of its members feel otherwise at present (which I doubt with regard to the best part of them) will very soon acknowledge the wisdom and justice of yielding to merit alone from whatever place it may come. If the interests of the University be consulted without reference to extraneous circumstances, there will be no difficulty in filling up the appointment in a manner entirely satisfactory to all parties in the end.

I am ever my dear Sharpey, sincerely yours

Allen Thomson

\footnotetext{
${ }^{1}$ Although written on Glasgow College notepaper this letter was composed in Edinburgh: see the previous letter.

${ }^{2}$ The Scottish University Act of 1858 provided for the creation of Courts with extensive powers to act as the governing bodies in all the Scottish universities.
} 


\section{7}

The College

Glasgow, $6^{\text {th }} \mathrm{Jan}^{\mathrm{y}} 1860$

My dear Sharpey,

There seems to be considerable difficulty in knowing the exact nature of the pressure which has been exerted from this [sic] upon the Home $\mathrm{Sec}^{\mathrm{y}}$. I have a note from Lister this morning from which it appears that there has actually been a deputation of the Glasgow doctors to wait upon Sir G. C. Lewis - It is a great pity that he should be influenced and imposed upon by such blustering. It is quite certain that these gentlemen unite in their cry about Glasgow only to serve each one their own friend here: and none of them are agreed upon the best man - The members lend themselves to this cry from other motives. I have had a variety of accounts of their partizanship The last I have got is that Walter Buchanan is not now for McLeod but for Flemingl and that Dalgleish is privately and personally for McLeod, but $w^{d}$ take up Fleming's cause if he could carry thus the question of the Glasgow man being chosen.

The real truth is that a larger portion of the profession have no sympathy with this and that the University people have none, and it is really most lamentable that the Home $\operatorname{Sec}^{y}$ should thus under false representation \& most absurd and futile intimidation yield up his judgment to such people who have nothing to do with it.

Pray let me know if you have heard anything.

Yours sincerely

Allen Thomson

I am quite persuaded that if the Home Secretary appointed according to his own judgment or the advice of a neutral man like Brodie no fault would or could be found. Some political influence must be telling upon him. I am told that Fleming has strong Manchester influence through his brother there.

You will be surprised at there being the doubt as to the sentiments of the Members here when I tell you most of what I have written in this \& previous letters has come partly directly from their own statements to persons I have seen.

There must be a good deal of manoeuvering. The Glasgow people take their stand upon this "that the professor should be a Glasgow practitioner" for why? No one can tell -

${ }^{1}$ John G. Fleming (1809-79), Surgeon to the Glasgow Royal Infirmary since 1846. 
68

The College, Glasgow

16th January 1860

My dear Sir Benjamin [Brodie]

I trust that the interest you take in the advancement of scientific instruction in medicine will lead you to excuse me for now addressing you on the appointment of a professor of Surgery in this University.

It appears that the filling up of the vacant chair has been delayed in consequence of a representation which has been addressed to the Home Secretary by a section of the Medical profession here, and which has been strongly seconded by one of the Members of Parliament for the City. This representation is to the effect that in the selection of a new professor a preference should be given to the claims of Candidates who are now practising in Glasgow.

It cannot be supposed that such a representation will by itself have the slightest weight with Sir George C. Lewis, who I am sure would at once reject the proposition in the abstract that the choice of professors for any of our national Universities should be limited to any locality or class. But it is nevertheless to be feared that when a Canvass for a chair has once begun, representations like these may in certain hands be made indirectly the means of favouring the interests of one or other of the Candidates, and there is no doubt that many who at another time would wholly repudiate such a doctrine, are either induced to support or are deterred from overtly opposing it by the fear of prejudicing the cause of individuals in whose cause they may feel a personal interest. But even as it is, I am glad to know that many of the most eminent men in our profession and the great majority of the intelligent part of the Community of Glasgow have no sympathy with the view which has been pressed upon the Home Secretary; and I feel persuaded that if a Canvass had not actually existed a very strong expression of opinion adverse to that view would have emanated from Glasgow.

I cannot help feeling extremely distrustful of the interference of Parliamentary men in such matters. In the present instance certainly, the opinion of the more enlightened inhabitants of Glasgow is not fairly represented, but on the contrary a view is upheld which tends to lower the character of the City for liberality and intelligence, and which is calculated to injure the best interests, and the reputation of the University. It may indeed be reasonably feared that Men who have no immediate connection with or interest in the University may be swayed by circumstances which have little reference to the advancement of learning but are closely connected with the relations subsisting between a Member and his political Constituency.

I feel assured that nothing would tend more to destroy the confidence which the University and the Community at large are desirous to place in the exercise of University Patronage by the Advisers of the Crown than the idea that any limitation to a particular class should be made in the choice of professors or that influences not directly connected with University interests should be allowed to operate in determining that choice. The Senatus of the University - as a body and individually have but one wish, which is to obtain the most eminent and the most desirable 


\section{Letter 69}

Colleague that can be selected from any quarter. They have already expressed through the Principal in a letter addressed to the Home Secretary their repudiation of the doctrine of a local limitation of the choice of a professor for this chair: And I would venture to suggest that if a doubt should still exist as to the proper person to be selected the Senatus or the University Court have a claim to be consulted in preference to those who cannot be supposed either to possess so much knowledge of or to feel so deep and immediate an interest in the superior excellence of the professor to be chosen.

My medical colleagues and I are well aware that the expression of your opinion on this matter would have the greatest weight with Sir G. C. Lewis, and we would feel deeply grateful if you could assist us in procuring for the University, irrespective of local or partial prejudices or predilections, the most eminent and scientific Surgeon and the most desirable Colleague to fill our vacant chair.

I am My dear Sir Benjamin

very respectfully $\&$ truly yours

Allen Thomson

to Sir B. C. Brodie Bart.

Pres. R. S. \&c. \&c.

69

London

18 th $\operatorname{Jan}^{\mathrm{y} \cdot} 1860$

My dear Thomson

I have been dining with Sir B. Brodie nobody but myself being a guest - I had received your letter before leaving home \& Brodie had got your Letter - but I am sorry to say he is quite averse to interfering in any way - He wishes to take no step unless applied to by the Government \& evidently does not wish to be applied to - He thinks that none can with propriety make any remonstrance to Sir G. L. except those interested - e.g. the Senatus, or the candidates -

I cannot believe that Sir G. Lewis can act upon the result of such a proceeding as is now being enacted ostensibly with his sanction-! It shows on the part of the Government a want of all consideration for the interest of the University, to allow this patronage to go as a sop to the Members - then the putting it to the vote of the "oi polloi["] of Glasgow registered practitioners - reckoning all votes equally good pennies shillings \& sovereigns all as equivalent units! ${ }^{1}$ It is a Scandal - and doubly so after the legislature had provided a proper tribunal to administer all patronage not royal - would Sir G. Lewis have treated Oxford or Cambridge after this fashion!

Send a letter to the Times with a copy of the circular - giving your name or some others equally good as a guarantee of truth, although any non de plume may be used in public.

I feel quite powerless in the matter.

What security has Sir G. L. that the unsigned crosses in Mr. Dalgleish's List represent the opinions of the persons to whom they are assigned? 


\section{Letter 70}

It is very distressing-but after all the best counteraction is a very decided remonstrance from the Senatus - accompanied by an exposure of the real nature of the proceeding.

Brodie expressed himself very much pleased with your selection to the [General] Medical Council.

Ever yours most sincerely

W Sharpey

Dr. Allen Thomson

FRS.

\footnotetext{
I In January 1860, the Glasgow MPs sent a circular to all medical practitioners in the Glasgow area asking them to indicate the candidate they thought most suitable to fill the Surgery Chair. For the text of the circular see: Med. Times \& Gaz., 1860, 1: 122.
}

70

Wrote 22nd [This is in Thomson's hand.]

33 Woburn Place

20th Jan 1860

My dear Thomson

I have your letter of the 19th and I have seen Thursday's Scotsman - which is far too tender with Sir G. Lewis. ${ }^{1}$

I think he has behaved unworthily of the trust reposed in him, to yield to political pressure at all in such a case - I do not make him immediately responsible for Dalgleish's notable proceeding, but he had no business to make the interests of the University and of Medical Education in Scotland subordinate to the gratification of a political supporter. At the same time it is quite possible that the Members worked on Sir G. Lewis through some other member of the Cabinet-perhaps Palmerston himself, who I suppose does not care if the Glasgow Chairs are dealt with as "fish guts." The best of the joke is that Sir G. Lewis is allowed to have made the most effective Speech against the Ballot in the recent discussions of this subject-and through his means Election by ballot has been attempted in the case of an academical Professorship!

Sir James Graham, with all his inferiority in many other things, managed better in the affair of patronage.

To speak of another Graham (the Master of the Mint). He asked my opinion about a month ago about the Candidates, when of course I spoke most decidedly for Lister - Graham had been canvassed by some Glasgow candidate who was an old personal friend - not McLeod - My opinion had the effect of preventing Graham from moving for his friend - but in the circumstances I fear I could not ask him to be urgent for Lister - and unless he were to take up the cause keenly - I don't think his interference could have any effect.

I am told that Sir G. Lewis likes to share responsibility when he can - I fear if some Glasgow candidate is pressed on him, he will not ask an opinion (say from Brodie) as to 


\section{Letter 71}

the best, but whether Mr. Dalgleish's man is quite competent for the office - and select him if the answer be favourable.

I am glad to hear that Mr. Buchanan is sensible of the false step he has made in cooperating with his colleague in the matter-The M.P.s should not concern themselves about University matters unless of such as they are themselves conversant with - or on which they have been instructed to take part either by the University people or by persons who have grievances to complain of against the University.

But Post-time is come "So no more[?] at present but [. . .]"

Yours most sincerely

Dr. Allen Thomson

$$
\text { W. Sharpey }
$$

What side does William Thomson ${ }^{2}$ take? if the right one, his exertion might do good -

\footnotetext{
${ }^{1}$ The Scotsman of 19 January 1860 published a leading article that described the Glasgow MPs' ballot of the local medical community as a " discreditable bit of jobbery", but which absolved the Home Secretary of blame for the manoeuvre.

${ }^{2}$ I.e., William Thomson (1824-1904), the future Lord Kelvin, Professor of Natural Philosophy at Glasgow.
}

\section{1}

College, Glasgow

16th Dec. 1860

My dear Sharpey

I am ashamed not to have written you before this: but as usual and as you know full well the early work of the session absorbs one's time and attention so much as not to favour or dispose to letter writing.

You will have heard I daresay from Syme or some other quarter of Lister's success which has been most gratifying to me. He has actually 180 in his class more than forty above the number of last year and larger than the Surgery class has been for long. His lectures give entire satisfaction to the students and they listen to him with the closest attention. Then he is intensely interested \& highly pleased himself and his Colleagues are all quite taken with his pleasing manner and satisfied with his success. He had had a number of consultations $\&$ operations from different practitioners so that in practice also his prospects are good. And there seems to be no doubt that he will get the next Surgeoncy in the Infirmary -

My class is also large, in fact the largest I ever had, owing to the very large number of entrants of last year and a good continuance this year. I have 253 in all - so that I had to get some additional seats placed in my classroom. The number of beginners last year was about 110 - this year it is about 100, and I daresay it may come down next session as I do not think the present plethora is to last. At the same time I think our school will keep its place well as compared with Edinburgh in consequence of our great advantages for dissection. 
I have heard nothing from Koelliker nor have I seen his Embryology, ${ }^{1}$ altho' I see the first part advertised as published. Young Andrew Buchanan ${ }^{2}$ is very desirous to translate the work and has I think been in communication with Koelliker about it. He is somewhat priggish and confident, but on the whole much improved by his travels, and he has recently taken off his beard, which is a sign of increasing good sense.

I am looking up the larynx and voice as well as the ear \& hearing in connection with a public lecture I have to give soon in the Corporation Rooms. Can you tell me of any thing good on these subjects within reach. Is there anything on the function of the Cochlea since Cortis ${ }^{3}$ observations. I have been looking at a paper by Mr. Garcia in the Roy. Soc. proceedings on the singing voice. ${ }^{4}$ Will you tell me who he is and whether you think his observations can be trusted. He is not very clear about falsetto notes and I cannot make up my mind on this subject. I think the recent Germans such as Ludwig \& Ecker $^{5}$ are wrong in supposing that the posterior part of the glottis forms an open triangular chink during vocalisation: for though it is true that the basis of the arytenoid cartilages cannot be brought quite close together, this part of the glottis is quite shut by the approximation of the upper part of the cartilages - Most authors seem to me to have fallen into error chiefly by considering the actions of the muscles individually; whereas they must be taken together. It is to me quite clear that vocal position in ordinary voice is given by the crico thyroid, crico-arytenoideus lateralis and the arytenoid muscles: but I cannot make up my mind about the action of the thyro-arytenoid. Garcia's observations as to its forming arches or loops on the outside of the vocal cords are curious and as far as I can see correct, and I do not think that the action which they may have on the vocal cords has been sufficiently studied.

Our holidays will begin I think on Saturday the 22nd when we shall go to Edinburgh for some days. I wish much you could find time to write me soon as we are wearying to hear of you.

Mrs. Allen has had a curious neuralgic affection of the arm, at first very painful, but now only wearying \& troublesome - she tried quinine first \& is now taking Colchicum, but not with any marked effect.

I send enclosed a print done here of my negative portrait of you - from which I removed the halo, and which has been done in the vignette style to get rid of the scratches at the side. I think it the best we have got of you \& beg Miss Colvills acceptance of it with my best regards.

Ever most sincerely yours

Allen Thomson

\footnotetext{
${ }^{1}$ Albrecht von Kölliker, Entwickelungsgeschichte des Menschen und der höhern Thiere, Leipzig, W. Engelmann, 1861.

${ }^{2}$ Andrew Buchanan (1834-65), Glasgow medical practitioner.

${ }^{3}$ Presumably F. Cortese, 'Delle recenti scoperte degli anatomici sulla struttura e sugli uffici della coclea', Annali univl. Med. [Milan], 1854, 149: 309.

${ }_{5}^{4}$ Manuel Garcia, 'Observations on the human voice', Proc. R. Soc. Lond., 1854-5, 7: 399-410.

${ }^{5}$ Presumably Carl Friedrich Wilhelm Ludwig (1816-95), and Alexander Ecker (1816-87).
} 
72

33 Woburn Place, London WC

4th March 1863.

My dear Thomson

I am amused to think that I should be in a position to receive excuses from any body for remissness in correspondence! No one is more conscious of standing in need of indulgence. Never the less the lapse of time since I had your last has been truly owing to the fact that the letter referred to business on which I was rather indisposed to enter - I mean that "weary Quain's Anat ${ }^{y}$ "1 - I have talked with Walton, with Marshall \& (today) with Ellis. Walton seems convinced that it would not pay him to publish a new edition on the existing plan - that it will need to be reduced in extent \& illustrated with larger figures. I doubt if the idea of a separate Elementary Atlas of Anatomical Figures will be persisted in. It seems preferable to enlarge the size of the page of the Book to Royal Octavo and introduce large figures into it. Now I find that Ellis thinks Walton ought to keep the Book as it is - with more illustrations - but not abridged - At any rate he cannot undertake to abridge his part for then he says he would need to re-write it, and this he could not do. I am quite willing to curtail and excise or compress so far as my part is concerned - and I begin to think the book must be either reduced or extended - extended, viz., if it is to take the place of a full system. But a full Treatise will perhaps some day or other be undertaken by an association of writers (a la Soemmerring's Anat ${ }^{\mathrm{y} 2}$ ) and therefore I am reconciled to the reduction. Still in the Descriptive Anatomy I think no actual insertion or process or foramen or branch of an artery should be left out. The details of description may be shortened but it must be understood that everything's noticed.

In my part I should omit all discussions - shorten descriptions and deal with questions more dogmatically but I see that many figures in addition to or substitution for those existing will be needed.

Now Ellis having declined, we must think of another Editor - Walton fears that you would find it irksome labour \& would not come up to time. I grudge recommending anything to you that you might feel as a drag on better work - but if you could like it and think you could work on it pleasantly I should at once get him to arrange with you, to cut down and dress the text \& direct the preparation of the hardest cuts. Failing you I have suggested that probably Dr Cleland ${ }^{3}$ would undertake the duty, and it would be a recommendation that he could advise with you when required.

My view of the present state of the case is therefore as follows.

1. Walton will not keep up the book at its present bulk.

2. Ellis will not reduce his part, but willingly abandons the text to another.

3. The Figures will be needed in the book to give it a fair chance of sale, with competing publications.

4. You or Cleland - or you and Cleland -, if you were willing, might very well edit the Descriptive Anatomy - i.e. including the organs of the Senses, and also the Brain, which last was my work. Pray think of this proposal - \& if you approve of enlisting Dr Cleland be so good as open the matter to him.

Yesterday \& today have been days of warm sunshine - too warm I fear for the salutary discipline of the growing crops. Naturally we wish Saturday may be as good 


\section{Letter 73}

after all people are excited less I think by curiosity to see the procession, than by desire to testify interest in the advent of the young Princess - \& to show good will towards her - and the Queen's family. ${ }^{4}$

Mary received the portraits this morning - she is not at this moment in the house but I may take upon me to thank you in her name for your attention. A Letter from Helen last week informed me of Ninian's proceedings $\&$ his sisters arrival in India - also that your windows at Moreland were in.

With kind regards to Mrs T. \& Johnny -

Yours ever sincerely

W Sharpey

Dr Allen Thomson

\&c

P.S. What a mess Owen has got into! observe how he tries to hedge. ${ }^{5}$

\footnotetext{
${ }^{1}$ I.e., the seventh edition of Quain's Elements of anatomy, published in 1867 by J. Walton with Sharpey, Thomson, and John Cleland as joint editors.

${ }^{2}$ Samuel Thomas Soemmerring, Vom Baue des menschlichen Körpers. Neue umgearbeitete und vervollständigte Original-Ausgabe, Leipzig, L. Voss, 1839-45.

3 John Cleland (1835-1925), Thomson's assistant in the Glasgow anatomy class.

${ }^{4}$ On 5 March 1863, the Prince of Wales was married to Princess Alexandra at St George's Chapel, Windsor.

${ }^{5}$ A reference to a controversy between Richard Owen and T. H. Huxley over whether the human brain was structurally distinct from that of apes. Although taking Huxley's side in this dispute, Sharpey had in 1862 rejected a suggestion from Huxley that Owen be excluded from membership of the Council of the Royal Society because this would appear to endorse his claims: Sharpey to Huxley, 13 November 1862, University College London MSS, Add. 227/4. 1862 107-129 (123).
}

\section{3}

College Glasgow

10th March 1863.

My dear Sharpey

In reply to your inquiry in yesterday's letter I may say that no time is yet known for the election of a Professor of Latin in Ramsay's ${ }^{1}$ place for this reason - in the first place that he has not yet given in his resignation. His intention is I understand, following the course now prescribed by the Commiss ${ }^{\mathrm{rs}}$ Ordinance, to send in his resignation to the first meeting of the Univ ${ }^{y}$ Court which will not be till after Lord Palmerston has been here on the 30th of this month. It must then go before the Privy Council to receive their approval before liberty to resign can be obtained; and after all that the applications of Candidates must be received and other meetings of the Court held for the election. I scarcely think it can be made before the middle or end of May.

With respect to the new edition of Quain and the Anatomical plates I had, on trying the arrangement of the thing by myself, come very much to the same way of thinking with Mr. Walton and you. I found in the first place that we could not exactly copy with advantage any existing plates, at least that we could only copy some and would need 


\section{Letter 73}

either to supply or to modify others; and I found upon trial that I would not be satisfied with the most of them if I had not drawn them myself, or at least had given as much time to the preparation as would enable me to do them myself. I therefore abandon the plan to have a small system of plates suitable for students, though I think it a great pity that this cannot be had. The nearest thing to a suitable work of this kind I have seen is a new edition of Bock's Hand Atlas. ${ }^{2}$

As to the Textbook I am still of the decided opinion that we have not yet got the requisite students book, and that Quain contains all that is necessary if modernised properly and shortened by leaving out all words and statements that are superfluous. I would not on this account leave out any particulars in description; but I think it could be greatly shortened, and much assistance could be given by more tabulation and employing different kinds of types. The descriptive Anatomy alone should not exceed one volume. As to the illustrations I have come to think that much might be done by adopting a large size, as you suggest; And what helped to bring me to this view was the sight of a book lately published by d'Alton on the organs of motion ${ }^{3}$ by which he means the Bones Joints and Muscles, beautifully illustrated, and the woodcuts of a size which quite satisfies me viz. a little larger than Grays. You should take a look at it. The woodcuts of the Bones are the finest things of the kind I have seen: but unnecessarily large. The muscles are rather too tame in the execution but the plan is good.

Now as to editorship, Mr. Walton and you seem to have a correct notion of me when you fear I would not be up to time. I had no doubt that Cleland would do it well and like it, and therefore I spoke to him at once; and he expressed himself much pleased with the proposal and ready to undertake it. At the same time though I cannot undertake to go through the drudgery of the whole I should like much to be associated in the work, for I feel that I have got experience of a number of things which I could made very useful in a students book, and which if I am allowed to introduce, may tend to satisfy me so much as to promote greatly the sale of the work in Scotland.

I should like therefore to have my name associated with yours as one of the editors, and Cleland should be assumed to do the hard work. He will have great advantages in doing it here with a dissecting room and good library at his disposal. I would write more on this subject. but we are just preparing to go out to see the illuminations, and I have my hands full of other matters.

It has been most gratifying to see the accounts of the procession \&c. in London going off so well: And altogether the popular enthusiasm and cordial good feeling to the Queen and her family have been most delightful. ${ }^{4}$ I have just been to a morning entertainment given by the Town authorities at which great satisfaction has been expressed and there are to be public dinners \& balls of various kinds in the evening.

We are having also a torch light procession of the students to the number of about 400 which causes me some anxiety: but I hope it will all go off well.

Owen's long sentences \& grandiloquent \& obscure phrases are very funny: but I wonder the Londoners are not tired of the Gorilla's brain. I have found my drawings of the Chimpanzee's again: but I should be ashamed to publish now as I once intended -

With kind regards to Miss Colvill \& to your self from Mrs. Allen I am

Ever sincerely yours

Allen Thomson 
${ }^{1}$ William Ramsay (1806-65), Professor of Humanities at Glasgow from 1831 to 1863.

${ }^{2}$ Presumably, August Carl Bock, Chirurgische-anatomische Tafeln; oder Abbildung der Theile des menschlichen Koerpers in Bezug auf chirurgischen Krankheiten und Operations, Leipzig, Voss, 1833.

${ }^{3}$ Edward d'Alton, Die Anatomie der Bewegungswerkzeuge; oder, Knochen-, Bänder- und Muskel-Lehre des Menschen, Leipzig, H. Hunger, 1862.

${ }^{4}$ See note 72.4 above.

\section{4}

Wrote 4th Jan, 1864

33 Woburn Place WC.

31. Dec. 1863

My dear Thomson

In determining a time for the Gen ${ }^{1}$ Council meeting we did not forget the case of Professors \& Lecturers - but the Christmas Holidays would have been complained of because of too short warning \& perhaps interference with engagements settled beforehand for that time of year. A Monday was objectionable because Scotch Sabbatarians would be brought away on the previous Saturday. Saturday itself was liable to the risk of detention till Monday for the same reason-Supposing too the possibility of an abridgement of the Meeting till the morrow, Friday \& Saturday were both objectionable. It is always uncertain how any proposed arrangement of days will affect twenty people distributed in England, Scotland \& Ireland. But, after all, the time was open to suggested change.

Your Pupils cannot suffer from want of four or five Lectures - especially now as the maxim seems likely to be "the fewer lectures the better" - always excepting those on Clinical Surgery delivered in Edinburgh by an old and valued friend of mine whose name begins with $\mathbf{J}$. S.

Pray let me know whether you are coming up.

You will be sorry to hear that Dr. Watson ${ }^{1}$ definitively declines being put in nomination for the Presidency. I now see no course to take but to elect Burrows ${ }^{2}$ or take some non Professional personage - If we could get a retired $\mathrm{L}^{\mathrm{d}}$. Chancellor or Literary Judge - or some Nobleman known to take an interest in Literary or Scientific matters, I think we might do worse than choose him. Men in the Government I fear could not afford the time. Try and think of somebody of this class. On casting about in my own mind I confess I can find no one just exactly fitting. Then a Council of Doctors is so professional! A retired high Functionary like Lord Canning ${ }^{3}$ or Lord Elgin ${ }^{4}$ could such be found would suit well.

I have a note from Burrows today inclosing Watson's Letter to him with his final negative answer - Burrows thinks we must turn to some non-professional - but perhaps he does not know that several members would be well pleased to elect himself.

Lister called on Monday - we had a long chat but he is always full of his own matters - inflammation \&c - so that I could get little out of him about things in general.

I have a letter from Acland ${ }^{5}$ after he had read Syme's address ${ }^{6}$ - The burden of it is consolidation of Examining Boards - which doubtless is most desirable - that is to say if friend Syme will allow any examinations except class examinations subject to 


\section{Letter 74}

Andrew Wood's ${ }^{7}$ sensible Inspectors. In London the Colleges of Surgeons \& Physicians ought to form a joint Board of Examiners to confer the common Licence. There ought to be a single board for conferring Medical Degrees in England, the like for Scotland \& for Ireland. But Oxford \& Cambridge would scarcely relish this - The Scotish [sic] Universities still less - the great desire of their Professors is to keep hold of the Examinations. Could it only be practically brought about that regular attendance and steady attention throughout a course were made to weigh at an Examination for Licence or Degree I should be very glad to see such consummation - but what are you to do with particular teachers! must you treat all equally?

The cry of too much lecturing is in great part not well founded - it is but a cry. When I was a student the Edinburgh Courses were just as long as now. $\mathrm{Hope}^{8}$ always cut into May. Barclay ${ }^{9}$ towards the end joined his morning \& evening course so as to make two progressive lectures daily and at last had a third one in the morning - \& goodness knows he wasted much time in talking about muscles \&c. His account of the Ear had to be comprized in half an hour so wasteful was he of time in the earlier parts of the course. Syme talks of "refinements" \& "minutiae" and the like - but in this way an old man might always stop progress - like Dr. French ${ }^{10}$ of Aberdeen who complained of a Young Man called Davy who was making troublesome innovations in chemistry. I cannot suppose Playfair's ${ }^{11}$ Course is longer than Hope's and therefore I infer he makes a selection from the multifarious matter of modern Chemistry. I am quite agreed that certain Scientific branches auxilliary to Medicine are not to be taught or at least examined in the same detail as fundamental subjects such as Anatomy - But to tell the truth I would rather leave out certain things \& allow the Student to learn the rest well, than try to squeeze all into smaller compass. Botany has no business as a branch of Medical Education. It came in originally into the M.D. curriculum because it comprehended Materia Medica I certainly should not exact both Botany \& Zoology - A reasonable foundation in at least one classificatory science I think is proper - but it is unreasonable to exact details of particular parts. - Then Materia Medica \& Midwifery should be Summer Classes. Lastly - there should be no double attendances required, on any lectures whatever - not even on Anatomy. Some students will find it to their advantage to attend twice or even more - others will fix or extend their knowledge in other ways but by not exacting repeated attendance there would be ample time left for practical work - especially if the winter session were relieved as in London by the transference of certain classes to the Summer.

There is however a great fallacy running through all this outcry namely - that whatever time is saved from lectures is diligently employed in private study! or in Clinical instruction. To many students the Hospital is a mere lounge. Clerks[,] Dressers \& House Surgeons profit by it - the bulk of students learn very little.

I am glad Cleland has succeeded - I had little expectation of Waller's Candidature, ${ }^{12}$ but it was suggested by a Dublin man - and I wish much he could get something - You rightly judge that Anatomy is not his forte, but he would have got on. However I don't think the election lay between him \& Cleland \& trusting you may find an adequate Successor \& laud his success. I have barely room to wish you a happy new year

$$
11 \text { p.m. W. Sharpey }
$$




\section{Letter 75}

\footnotetext{
' Presumably Thomas Watson (1792-1882), Consultant Physician to King's College Hospital and a former member of the General Medical Council.

${ }^{2}$ George Burrows (1801-87), Physician to St Bartholomew's Hospital and Treasurer of the GMC.

${ }^{3}$ Presumably Charles John Canning (1812-62), who retired as Governor-General of India in March 1862. However, Canning had died in London in June of the same year-a fact which seems to have escaped Sharpey.

4 James Bruce, eighth Earl of Elgin (1811-63), a former Governor of Jamaica and Governor-General of Canada. He was appointed Governor-General of India in Canning's place.

${ }^{5}$ At this time Acland was Regius Professor of Medicine at Oxford.

${ }^{6}$ See 'Mr Syme on medical education', Br. med. J., 1863, ii: 692-4.

${ }^{7}$ I.e., Andrew Wood, the Inspector of Anatomy in Scotland.

${ }^{8}$ Thomas Charles Hope (1766-1844), Professor of Chemistry at Edinburgh from 1795 to 1844.

9 John Barclay (1758-1826), a private lecturer in anatomy in Edinburgh.

${ }^{10}$ George French (1765-1833), Professor of Chemistry at Marischal College, Aberdeen from 1793 to 1833.

${ }^{11}$ Lyon Playfair (1818-98), Professor of Chemistry at Edinburgh from 1858 to 1869.

${ }^{12}$ Cleland left his post as demonstrator to Thomson's class in 1863 to become Professor of Anatomy at Queen's College, Galway. Evidently, Augustus Volney Waller (1815-70), sometime Professor of Physiology at Queen's College, Birmingham, was also a candidate for the position.
}

\section{5}

My dear Thomson

33 Woburn Place 12th July 1864

I had a Letter from Koelliker on Saturday to which I replied by return of post. He announced his intention of being here on his way to Scotland soon after 8th of August.

I told him we expected a visit from you \& Mrs. T. about that time, but that never the less we should be happy to receive him \& his party as you would find quarters with the Grahams or some other friends.

Now I find you have abandoned your plan. I declined an invitation from Dr. Paget ${ }^{1}$ to go to Cambridge. The occasion of a "Gathering" is the very worst for seeing such a place as an University Town - for the "natural life" of it is gone for the time; and a collection of General Practitioners with a sprinkling of M.D.s forcing you to attend morning meetings \& evening converzationes - is bad employment for vacation time. I suppose the Koellikers will stay with us two or three days at farthest. When you write to Würzburg entreat of them not to delay coming - for otherwise they will probably find the town empty of their friends I know that Busk is going to Gibraltar to explore Caves; but when I do not exactly know. Mary has written to Mrs. Carpenter to learn about their movements - (also to Mrs. Busk) \& she will write as soon as she gets an answer.

I propose that Mary should go down to Skelmorlie with the Koellikers. I am sorry to say that as usual I have yielded up my time to others so much, or squandered it away - that I must stay in London to do something towards the Histological part of Quain's Anat ${ }^{\mathrm{y}}$. How I hate the title! I have decided to stay here till the middle of September - and make a very short visit (at least compared with my wishes) to Scotland this year.

So Lister will in all probability leave Glasgow, and you will be again in the hands of the Home Office. ${ }^{2}$ I hope you will find a Successor who will be marked for superiority 
in Something - If not an original contributor to the Science of Surgery - that he should be a Good Operator - or Good Lecturer - and especially a Good man.

Yours always most sincerely

W. Sharpey

P.S. Mary had a letter from Mrs. Mylne the other day dated from somewhere near Naples. They are about to return to England - and mean to take lodgings for a short while in London near the west end parks.

Will Koelliker go to the Bath Meeting of the Brit Assoc ${ }^{\mathrm{n}}$ - which begins on the 14th of Sep? ${ }^{\text {t? }}$ Lyell $^{3}$ to be President.

${ }^{1}$ George Edward Paget (1809-92), Linacre Lecturer on medicine at St John's College, Cambridge.

2 Lister did not, in fact, leave his Chair in Glasgow until 1869.

${ }^{3}$ Charles Lyell (1797-1875), Scottish geologist.

76

My dear Thomson

33 Woburn Place London WC

25 Oct. 1864

It has seemed to me worth while to draw your attention to a muscle of the hand said to be often present (by Henle and by Mr. Wood Proc. Royl. Soc. Vol xIII p 302.) ${ }^{1}$ It is a palmar interosseous muscle going to the dorsal aponeurosis of the thumb.

I am much pleased with the figures of the vertebral muscles. The old ones looked very pretty - but the new ones with the muscles raised to show the steps [?] of attachment are much more useful. Indeed they seem to me unique.

I think that in the "Advertisement" prefixed to the part of the work which will first appear - it may be expedient to give some explanation in reference to the figures. - It might be stated, for example, that the question of marking the objects with the names (putting the names of the parts on the figures) had been well considered - but as this can seldom be effected with exactness, the spot being often much smaller than the title, and as it tends to obscure and disfigure the delineation - it was not adopted Then - that great care had been bestowed in placing the reference letters \& numbers so as to make the explanation as descriptive as possible. Also that the figures of the bones are taken from the actual object $\&$ the figures of the muscles in many cases finished from actual dissections. \&c. \&c.

Our new entries at the College this year are much the same as last - that is small - and this being the third year of small entries it tells unfavourably on the whole numbers. I know nothing of the other schools save from the statement of general deficiency in the Lancet.

What a dance A. Wood has led us into on account of the alleged refusal of the Irish Poor Law Commissioners to employ Surgeons who have not a special licence in Midwifery. It turns out that they accept a certificate from any Licensing Body that 
examines in Midwifery - \& that last year two such certificates were actually accepted as sufficient from the Coll. of Phys. of Edinburgh signed by Dr. Burt! ${ }^{2}$ In the whole of that business the Scotch have been thoroughly "licked" by the Paddies. ${ }^{3}$

Yours always sincerely

Dr. A. Thomson

$$
\text { W. Sharpey }
$$

\footnotetext{
' John Wood, 'On some variations in human myology', Proc. R. Soc. Lond., 1864, 13: 299-303.

${ }^{2}$ Presumably John Graham Macdonald Burt, a Fellow of the Royal College of Physicians of Edinburgh.

${ }^{3}$ These remarks appear to refer to some discussion in the GMC, but I have been unable to discover their context.
}

\section{7}

33 Woburn Place WC

London Feb 181865

My dear Thomson

As regards Carter $^{1}$ (of Leamington)'s researches - of course you know they are intended to prove by injections a doctrine somewhat the same as has been entertained by Virchow, Heidenhain, Recklingshausen ${ }^{2}$ \&c. - A communication between blood capillaries and lymphatics through the medium of so called plasmatic channels - at least this is nearly the pith of the matter. I have seen Carter's drawings, and Marshall \& Beale ${ }^{3}$ examined carefully a selection of his preparations sent up here for the purpose. At that time I was otherwise engaged and did not investigate them. M. \& B. thought the evidence afforded by the preparations not satisfactory.

You and I know well enough that the mere passage of injections from one class of vessels to another is no proof of natural intercommunication. These transparent injections, such as Dr. Carter used are so liable to transude and stain extravascular objects, that, although Dr. C. thinks this was sufficiently guarded against in his experiments, I have very little faith in such proofs. We could in fact get appearances from mere immersion in carmine \& other coloured solutions, showing channels filled with the material - i.e. their contents coloured by it. A nucleus in the centre of a so called plasm cell or connect ${ }^{\mathrm{v}}$. tissue corpuscle will become stained while the surrounding matter is comparatively untouched. But I am satisfied the doctrine that the connect ${ }^{\mathrm{v} \cdot}$ tissue corpuscles are really ramified cells must be given up - if it is thereby meant that they have a cell wall and that their branches are tubular. I believe Virchow himself is now driven to admit that the bodies in question lie in interstices of tissue which give the appearance of a branch cell with cell wall and contents. The lymphatics may begin in these interstices, and the nature and motion of their fluid may be influenced by the plasm corpuscles which lie in these interstices. There appears to me much less evidence in favour of a communication of these intersticial passages with the blood capillaries. In any case I don't think Dr. Carter has added anything to the existing evidence for either doctrine. 


\section{Letter 77}

As to Dr. Beale's "paths of the nerve currents" 4 will not venture to speak till I have seen more of his preparations.

He tortures the things so much with chromic acid, glycerine \&c. - that one feels uncertain as to the appearances of fibres. You remember the mistake of Brücke (or was it Hannover?) ${ }^{5}$ who after steeping an eye in a chemical solution (alum, or sugar of lead?) found the vitrous humour to be concentrically laminated like an onion. Now suppose a nerve fibre thus acted on - in section [drawing here, see figure 7] - in profile thus, [drawing here].

I by no means would have you to understand that I have this or similar doubts about all Beale's preparations - but in some others of them the nerve fibres are shown only with very high powers, and they seem to run out at the end into fine threads which look like clear transparent lines or streaks; and indeed unless I make myself familiar with "twenty fifths" and perhaps with "fiftieths" - I could scarcely pass a judgment. Moreover you know better than I how necessary it is to work out the observation for yourself from the beginning, \& how unsatisfactory it is to be shown perhaps a single fortunate specimen to prove a difficult point.

I think you may take it for settled that the Med Council will meet on the 4th of April at which time (or sooner if you like) we shall be prepared as usual to receive you; and Mrs. Thomson if she will come. I have written to Giraldes to say that we all assent to his proposed translation. ${ }^{6}$

\section{Dr. Allen Thomson}

$$
\begin{aligned}
& \text { Yours always sincerely } \\
& \text { W. Sharpey }
\end{aligned}
$$

\footnotetext{
${ }^{1}$ Thomas Albert Carter, 'On the distal communication of the blood vessels with the lymphatics; and on a diaplasmic system of vessels’, Proc. $R$. Soc. Lond., 1864, 13: 327-9.

${ }^{2}$ Rudolf Carl Virchow (1821-1902), German pathologist; Friedrich Daniel von Recklinghausen (1833-1910), German histologist and pathologist; and Rudolph Peter Heidenhain (1834-97), German physiologist.

${ }^{3}$ Lionel Smith Beale (1828-1906), Professor of Physiology and General and Morbid Anatomy at King's College, London.

${ }^{4}$ Lionel Smith Beale, 'Indications of the paths taken by the nerve-currents as they traverse the caudate nerve-cells of the spinal cord and encephalon', Proc. $R$. Soc. Lond., 1864, 13: 386-92.

${ }^{5}$ Ernst Wilhelm von Brücke (1819-92), German physiologist; Adolph Hannover (1814-94), German histologist.

6 Joachim Albin Cardoza Giraldès (1808-75), Spanish medical author. These remarks seem to refer to a proposed translation into Spanish of Quain's Anatomy by Giraldès; if so, the project appears not to have been executed.
} 
Letter 77

cavin th. that ow forls nacestasn os to the apfeararen of filues.: Gpu remennber he puitate of Bricke (or was it

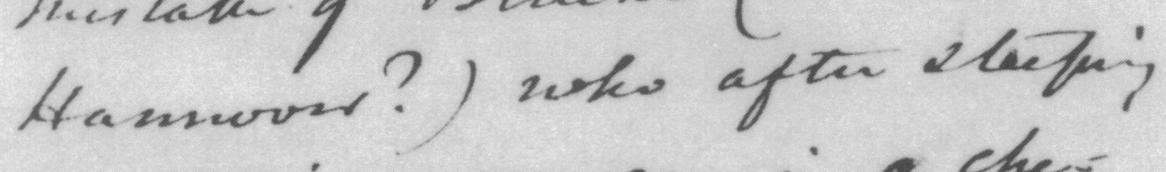
survion an eqe in a cher uncerobtin (alume, or sapar

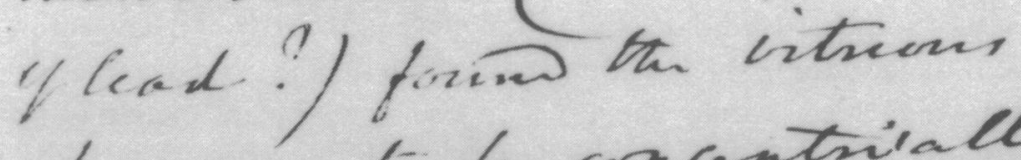
hasuover to h concentrially ancisated Cita an oxion. tho soppen a kenes fitie thes acted in - in Lechin (6) - in peopti Mi..,

I, no meart? watped han Yon 1 indertans thes I hase hisi or dimlar denbts abut

Figure 7.

121

https://doi.org/10.1017/S0025727300070903 Published online by Cambridge University Press 
78

33 Woburn Place, London WC

10th Dec. 1865

My dear Thomson

Since I last communicated with you I have sent to Mr Walton all that I intend to appear from me in the outcoming Part of the Anatomy. It is including the whole of Bone and a bit of Muscle. I was sorely at a loss for a better figure of the ossification of the Embryo cranium than the present figure 36' - but after trying one or two people here was obliged to send in my copy with the old figure, adding a caution on its imperfection. Since then I have got Marshall to try his hand at a preparation I made \& the wood cutter, after seeing the preparation, has taken in hand Marshall's figure. I sadly missed your kind and skilful hand.

I am glad to hear from a letter which Mary had yesterday from Helen, that Cowan ${ }^{1}$ has got the Materia Medica Chair. It is just one of those subjects that is not much pursued by the best men; and I should be disposed to prefer a good man who had a good deal to get up in the subject to a dull or mediocre one already known in that department. We had a choice of several some three or four years ago, when Garrod ${ }^{2}$ left us; Murchison ${ }^{3}$ was then a candidate, and as he is clever and active and had lectured on Chemistry \& Botany in India, I felt inclined to push his claims - but eventually we took one of our own people - Sydney Ringer $^{4}$ - who being a very able man has done the Materia Medica work very well, $\&$ besides he is one of the most promising Clinical men in England, and withal a very nice fellow; the last can hardly be said of little Murchison who has the reputation of quarrelling with everybody. (This is said privatim loquens). I feared you might have Fleming ${ }^{5}$ who was at Cork and latterly at Birmingham palmed upon you - The Aconite tincture Fleming.

I really wish you would send us in something by way of Report on Dr Wilson Fox's Paper on the Development of Muscle. ${ }^{6}$ Could you not get Lister (the other Referee) to take the first trouble \& you could join in his report if you approved it. There will be only one Meeting of Council before the New Year, namely on the 21 st Inst. (The next will not be till the $3^{d}$ Thursday of January) and we are anxious to get through arrears of Papers.

Sorry to hear of Ninian [Thomson]'s mishap - but the broken bone will mend. The non survival of their first born will no doubt be a great disappointment - but there will be more to come.

I suppose Frauenfeldt of Vienna sent you the account of his "Samuelreise"7 in which you are mentioned - and also a diploma of Membership of his Society, in which too I hope he had not forgotten Mr Robertson ${ }^{8}$ who I daresay would be gratified by the honour. For my part I may say unaffectedly, that these things are very indifferent to me \& I can only wonder how some people prize them.

With kind regards to Mrs T. \& John in which Mary cordially joins - Always your sincere

W. Sharpey 
1 John Black Cowan, who became Professor of Materia Medica at Glasgow University in 1865.

${ }^{2}$ Alfred Baring Garrod (1819-1907) Professor of Materia Medica, Therapeutics, and Clinical Medicine at University College London until 1864.

${ }^{3}$ Charles Murchison (1830-79), former Professor of Chemistry at the Medical College, Calcutta (1853-4), was then lecturer on botany and curator of the museum at the Westminster General Dispensary. From 1860 he was Assistant Physician and pathologist at the Middlesex Hospital.

${ }^{4}$ Sydney Ringer (1835-1910), Professor of Materia Medica, Pharmacology, and Therapeutics at University College London (1862-78).

${ }^{5}$ Alexander Fleming (1824-75), Professor of Materia Medica at Cork and from 1858 at Queen's College, Birmingham.

${ }^{6}$ Presumably Wilson Fox, 'On the development of striated muscular fibre', Proc. R. Soc. Lond., 1865, 14: 374-6.

${ }^{7}$ Presumably Georg von Frauenfeld (1807-73), Austrian naturalist and traveller.

${ }^{8}$ Possibly Douglas Argyll Robertson (1837-1909), an extramural lecturer on diseases of the eye in Edinburgh.<smiles>[TeH]</smiles>

Huntingdon

Dec. 24th 1866

My dear Sir,

I had the honor [sic] of making your acquaintance several years ago at Aberdeen at the British Association. May I venture to presume upon that to ask your assistance in the following matter.

Through the resignation of Dr. G. Harley the post of Instructor in Practical Physiology and Histology at University College London has become vacant, and I am about to become a candidate.

For the last few years I have been busily engaged in practice in the country, and have had few opportunities for original research, but have never been able to keep myself from Physiology. For domestic reasons I have been obliged to remove from Huntingdon and give up my practice, and the post at University College having offered itself, I have determined to apply for it, should I succeed, my intention is to devote myself almost entirely to Physiology. If you can honestly say a good word in my favour I shall esteem it a great favour.

. I may add that Dr. Sharpey views my candidature very favorably [sic].

Believe me dear Sir

Yours faithfully

$$
\text { M. Foster }{ }^{1}
$$

Prof. Allen Thomson.

\footnotetext{
${ }^{1}$ Michael Foster (1836-1907), future Professor of Physiology at University College London and later at Cambridge. For particulars of his career up to 1866 see the next letter.
} 
80

Foster's Address at present is 3, Lansdowne Villas, Bournemouth

Wrote 4th Jan [This is in Thomson's hand.]

33 Woburn Place, London

2d. Jan 1867

My dear Thomson

I have just recd. the Draft of Michael Foster's application - The chief points are. B.A. of the Univ. of London gained the Classical Scholarship \& gold medal At Univ. Coll. gained Gold Medals in Chemistry and Physiology \& 2d place in Comparative Anatomy.

Was Assistant Curator of our Museum till obliged to go to the East for his health.

Whilst in practice in Huntingdon has carried on physiological investigations and published Papers.

List of Papers

On the beat of the Snail's heart. Brit. Assoc. at Aberdeen 1859.

On the effect of freezing on the physiological properties of muscles. Proceedings $\mathbf{R}$. Socy. 1860

Contribution to the theory of Cardiac Inhibition Brit. Ass. at Oxford, 1860

The Coagulation of the Blood. Nat. Histy Review April 1864. A Critical Essay, with corroborative original Experiments

On the existence of glycogen in the Entozoa Proc. R. Socy 1865

On Amylolytic Ferments Journ. of Anat. \& Physiol. No. 1 Nov 1866

Articles on Nutrition, Respiration and the physiological subjects in Watt's Dictionary of Chemistry

The life \& writings of Sir B. Brodie North Brit. Review Sept. 1865

The Elements of Muscular Strength Fortnightly Review Sept. 1. 1866

And other Papers.

You would do him a great favour if you would send him a Testimonial with your earliest convenience. ${ }^{1}$

In the course of last night Snow has fallen a good deal more than Ankle deep. -

I have just been shocked - very deeply - by hearing that Dr John Russell ${ }^{2}$ has killed himself -

Wishing you \& yours many happy returns of the New year

Yours always sincerely

W. Sharpey

\footnotetext{
${ }^{1}$ Foster's application for this post was successful; it marked the start of his career in physiology.

2 John Rutherford Russell, an Edinburgh MD resident in London, was reported to have hanged himself in January 1867. See: Br. med. J., 1867, i: 15 .
} 


\section{1}

Hampstead, London N.W.

15th November 1868

My dear Thomson,

Conscious of blameworthiness I was ashamed to be reminded in a note from John Marshall last night that I had so long delayed communicating with you. We were none the less interested, however, in your great doings in Glasgow, and eagerly read the accounts of your grand Ceremony. ${ }^{1}$ The fault was that one who like yourself, has from the first to last worked so steadily and effectively in promoting the undertaking should not be singled out for special honour. Not that I wish to see you be-k-nighted like the worthy Provost - but your Portrait or Bust ought to occupy a conspicuous place in the great Palace; and I trust it will do so in time.

I was more than two months on the Continent - in Switzerland, going as far as the Engadin. I profited considerably by my stay in the higher regions - but I made a wrong move at last in going to [. . . ] which was hot and relaxing, \& which there \& in Geneva I was never far from a severe Cold. But in Geneva I was much pleased to meet Lombard ${ }^{2}$ who invited us to his house \& entertained us hospitably at dinner. We also visited Claparède ${ }^{3}$ who in Summer lives a couple of miles out of Town $-\mathrm{He}$ is presumably known to you I think.

From Geneva we went for three days to Aix les Bains in Savoy \& came down to Lyons on the Rhone Steamer. Ollier ${ }^{4}$ was found very kind - He is Surgeon to the great Hotel Dieu of Lyons - but I was wearying to get home so we made but a very short stay $\&$ came home by Paris. I feel very well just now. I take well with dry frosty weather, of which we have had a fair share.

Our classes both Medical \& Arts are good this year. I have 68 new entries (which means mostly perpetuals) last year at the end of the Session I counted 56. I presume Glasgow \& Edinburgh must also be good this year, but I have heard nothing. I shall not let so long a time pass before writing again - Mrs Storrar is now wonderfully well.

With most kind regards from Mary \& myself to you \& yours - I remain My dear Thomson

Yours most sincerely

W Sharpey

\footnotetext{
${ }^{1}$ A reference to Glasgow University's transfer to new premises at Gilmorehill. Thomson played a major part in the planning and execution of this move.

2 Presumably Henri Clermond Lombard (1803-95), Swiss physician and zoologist.

${ }^{3}$ Presumably Jean-Louis-René Claparède (1832-71), Swiss embryologist and zoologist.

${ }^{4}$ Louis-Xavier-Edouard-Léopold Ollier (1830-1900), Chief Surgeon at the Hôtel-Dieu of Lyons from 1860.
} 
82

Wrote 10th April. A.T.

Hampstead, London N.W. 29th March 1869

My dear Thomson

As on many former occasions I have to begin with an acknowledgment of my defaults in correspondence, and an expression of gratification for your last Letter.

We shall be delighted to see you here. You say about the 24 April (the $2 \mathrm{~d}$ Soiree at the RS). I hope you will not make a hurried visit \& that Mrs Allen will be with you. You will I hope see my Nephew $\mathrm{W}^{m}$ Henry $^{1}$ whom we expect to arrive from Bagdad [sic] by the end of April. He has now been thirteen years abroad. He held the place of Civil Surgeon at Bagdad in lieu of a Dr Wood who was at home on leave \& did not mean to return - but $\mathrm{Mr} \mathrm{W}$. has only lately intimated his retirement, and my Nephew is now confirmed in the appointment - so that it will be open for him when he returns to the East.

A meeting of the English Branch Council is summoned for the $31^{s t}$ (Wednesday next) and the time for assembling the Gen ${ }^{1}$ Council will not improbably be discussed - In which case I will let you know what is wished for in this end of the Island.

Storrar ${ }^{2}$ is dead against Syme as suggested for the Presidency [of the General Medical Council], his objections go beyond non-residence, which seems to be the chief or only objection entertained by others. Had we had an unexceptionable choice in London - the same objection to Syme would have prevailed with me. Last year I thought of Caesar Hawkins, ${ }^{3}$ but understood (from the President I believe) that he was unwilling to be brought forward. It now appears that this was a misapprehension; but in the mean time I declared my intention of supporting Syme and do not regret I did so.

The chief objection to non-residence is the short notice at which the President is generally required to hold interviews with the Members of the government. But as the request for such interviews almost always proceeds from the President himself there would be opportunity for arranging them to suit his time. After all it could only make a day's difference - and then the difficulty will not arise when the Council is in Session. I met Playfair the other day who strongly supported the election of Syme as a source of fresh interest and activity to him which would be most salutary after his recent bereavement.

We have had (as you know) a very mild winter - but of late we have been visited with cold frosty or wet winds - very trying. For myself I have kept wonderfully free from colds, I believe by being more careful.

I have for some time had beside me the Answers to the Queries of the Education $\mathrm{Comm}^{n}$ of the Med Council. I have not been in the humour to tackle them yet - I only hope there may be sufficient variety of authoritative opinion as will frustrate any proposal to make all medical teaching move at the same given rate on the same tread mill. 
We shall have time to talk over these and other things when you come.

Mary unites with me know in kind regards -

Yours always sincerely

W Sharpey

Professor Allen Thomson

\&c.

${ }_{2}^{1}$ William Henry Colvill (1833-85), a medical officer in the army.

2 John Storrar was the University of London's representative on the General Medical Council.

${ }^{3}$ Caesar Henry Hawkins (1798-1884), Sergeant-Surgeon to the Queen.

83

My dear Thomson

Hampstead London NW

$6^{\text {th }}$ Nov. 1870

I fear I can write you only very briefly - for I really have little or nothing worth telling you.

I am sorry I do not know Mr Redgrave [?] - but I have written to Seaton ${ }^{1}$ who moves a great deal among official people, in the hope that he may be able to serve $\mathrm{Mr}$ Johnstone - of whom I think he must [have] been a fellow pupil.

I am glad to say that Sanderson ${ }^{2}$ gets on well in our Practical Physiology Department. He has 34 pupils - not bad for a voluntary class with a rather high fee. I think moreover, that he will have two or three able young men to work at research in his Laboratory.

What we want in our Institution is Money. With four or five thousand pounds to lay out we could do wonders - but we have to work as well as we can with our small pecuniary means.

I read in yesterday's paper that there has been an unproarious demonstration in opposition to the new Professor of Midwifery in Edinburgh; ${ }^{3}$ and that both Sir A Grant $^{4} \&$ Christison were unable to procure him a hearing. Christison used to be very severe on untoward affairs of that sort which happened (exceptionally) in other schools; and used to vaunt the discipline of Edinburgh - but the peppering of Sir D. Brewster $^{5}$ with paper pellets which led for a time to the suppression of inaugural openings \& the riot now described - ought to make him more considerate. It is very difficult for an academical Authority to deal with cases of this kind when the whole of the class are offenders - To shut up the theatre would give them what they fight for $-\&$ you have difficulty in making a fair selection for an example. It might answer perhaps to make every one answer to his name when called out by an Officer of the Univ ${ }^{y}$ or run the risk of rustication $-\&$ the ringleaders might then be found out - but the task is very difficult when the fellows have a notion that they have good grounds for their opposition \& think that justice should supersede discipline.

Yours always sincerely

W Sharpey

Dr Allen Thomson 
${ }^{1}$ Presumably Edward Cator Seaton (1815-80), founder member of the Epidemiological Society.

2 John Scott Burdon Sanderson (1828-1905) succeeded Michael Foster as Professor of Practical Physiology and Histology at University College London.

${ }_{3}^{3}$ I.e., Alexander Russell Simpson (1835-1916), nephew to the previous incumbent, J. Y. Simpson.

${ }^{4}$ Alexander Grant (1826-84), Principal of Edinburgh University since 1868.

${ }^{5}$ David Brewster (1781-1868), former Principal of Edinburgh University. Sharpey is mistaken in stating that Brewster was peppered with paper pellets; the Senate Minutes make it clear that he was bombarded with peas: Edinburgh University MSS, College Minutes, 1861-5, vol 2, p. 451.

\section{4}

Hampstead 16th $\operatorname{Jan}^{y} 1871$

My dear Thomson

I am sorry I did not get your letter till I came home after post time tonight so that I could not write to you by return.

In Univ ${ }^{y}$ College there is a special Professor of Clinical Medicine and a special Professor of Clinical Surgery. Neither of these has any other chair in the College. Each has in-patients assigned to him in our Hospital.

Then the Professor of Medicine \& the Professor of Surgery in the College have virtute officii in-patients in the Hospital and are also styled Professors of Clinical Medicine and Professors of Clin. Surgery. I don't know the rule at other Institutions in London - but as a matter of fact the Professors or Lecturers on Systematic Medicine and Surgery have also Hospital charges.

I notice from signs of grumbling (in the Brit. Med. Journ) because your students cannot conveniently get to the Infirmary to see Dispensary Patients, ${ }^{1}$ and it occurs to me that you might at once open a place for out-Patients near the New College in attendant the full scheme.

I am glad to hear that John has definitely settled to be in London as his next move. I look on King's College as lucky in getting him. ${ }^{2}$

Please don't forget what I said about evidence concerning science from Glasgow - for the Royal Commission. ${ }^{3}-$

$$
\begin{gathered}
\text { Yours always sinc } \\
\text { W Sharpey }
\end{gathered}
$$

Dr Allen Thomson

\footnotetext{
${ }^{1}$ After Glasgow University removed to Gilmorehill, and before the opening of the adjacent Western Infirmary, medical students were put to considerable inconvenience; they had to travel some two miles from the University to the Royal Infirmary for clinical instruction. See Br. med. J., 1871, i: 41 .

2 I.e., Allen Thomson's son John Millar Thomson (1849-1933), who held a lectureship in chemistry at King's College London prior to his appointment as Professor.

${ }^{3}$ I.e., the Devonshire Commission on Scientific Instruction and the Advancement of Science, of which Sharpey was a member.
} 


\section{5}

Wrote $2^{\text {nd }}$ Feb. [This is in Thomson's hand.]

Hampstead $28^{\text {th }} \operatorname{Jan}^{y} 1872$

My dear Thomson

I was glad to have your agreeable letter of the 24. Dec. - and I am now able to write to you the at least closely approximate time of meeting of the Gen Med. Council. viz the $27^{\text {th }}$ of February, when of course we expect you as usual to be at Lawnbank - with Mrs Allen if she is disposed to move at all at this season.

I am glad to hear good accounts of your Class - The new entries at Univ ${ }^{y}$ College, which had risen for the last two years, have taken a great start this year - so that we head the list of New Students by a small majority. My new men (paying) are $=99$ and I can make out the 100 by counting an "Epsom Scholar" who goes free. The dissection is so active that Ellis has had to place tables in the middle of our large room \& increase the number at the sides. Mr Norman Macpherson is a prominent and estimable man, but he has got a capital bargain in Georgie.

The English scheme for common Examination has been formally agreed upon by the Colleges \& virtually by the Universities. ${ }^{1}$ It comes on for adoption by the U. of Lond ${ }^{n}$. next Wednesday - \& Paget apprehends no real hindrance in the other Universities. Andrew Wood writes to Paget rather disappointingly as to progress in Scotland; and Alex. Wood (I should say) contemplates Parliamentary proceedings taking place \& I believe he will get no one in this quarter willing to have recourse to Parliament until existing powers have been tried; and we hope that if the Med. Council sanctions our Conjunct Scheme under Section XIX. corresponding arrangements will be completed in no long time in Scotland \& Ireland. These should not be stereotyped by Parliament until we have had experience of their working. Eventually, legislative authority may be needed. For one thing, the conjoint Certificate can only be made indispensable for registration for the present by the Licensing Bodies agreeing to withold their separate qualifications (for registration) until candidates have passed the Common Exam ${ }^{n}$ but for permanent working it will be right to make the Common Exam ${ }^{n}$ the sole adit to registration, $\&$ then the Degrees and Fellowships may be conferred - as it pleases the Authorities - on Candidates whether they have the Common qualification or not.

Paget tells me he is cognizant of what is doing in Ireland. He is very hopeful - for thirteen very sensible resolutions have been agreed to by the Delegates of the Authorities - I say of the Authorities - but Aquilla Smith, ${ }^{2}$ who was in London on Thursday, speaks disappointingly of the Queen's University, which is completely under Corrigan's ${ }^{3}$ thumb-\& Sir Dominick is dissatisfied with the plan proposed - as he probably would be with any plan calculated to bring about a peaceful settlement.

I do not apprehend serious difficulties as to the imposition of further payments by Graduates. Should there be any difficulty at first it will speedily disappear - for the expenses of Medical Education dont keep pace with the increase of everything else \& with the growing wealth of the Community. Moreover I dont think that restriction to a 
Clinical Examination for men with degrees or fellowships would fulfil what is intended by a common qualification for admission to the Register.

The New Body will represent all the $\mathrm{Med}^{l}$ Authorities - Universities as well as Corporations, and the purpose is to guarantee on behalf of the Public the fitness of Candidates irrespective of Examination by single licensing bodies. It has been agreed to accept the Univ ${ }^{y}$ Exam. for the earlier branches of Study; as these are carried farther in the Universities than could be required by the Common Board \& further examination upon them would harass Students to no purpose - but this is in so far a concession on the part of the Conjoint Authorities, who are not the Corporations alone, and in principle the Common controlling Examination would apply to all subjects of the professional Examination. We all here wish very much that a Scheme for Scotland may be ready for submission to the $\mathrm{Gen}^{1}$ Council when it meets. If the three divisions of the Kingdom would agree to try each a plan for a term of years, the Med ${ }^{l}$ Council would be very much relieved from further work until the time should come for confirmation (after amendment if needed) by Act of Parliament.

Yours always sincerely

W Sharpey

\section{Dr A Thomson}

\&c.

\footnotetext{
${ }^{1}$ In 1871 the Royal Colleges of Physicians and Surgeons of London framed a scheme for a Conjoint Examining Board which would qualify for medical practice in England. The GMC had in 1870 advised the licensing bodies of its wish to see such conjoint examining boards; and similar bodies were to be established in Scotland and Ireland.

${ }^{2}$ Aquilla Smith (1806-90), Professor of Materia Medica and Pharmacy at Trinity College, Dublin and representative of the Irish colleges on the GMC.

${ }^{3}$ Dominic John Corrigan (1802-80), Irish physician, MP for Dublin, and Vice-Chancellor of the Queen's University of Ireland. He opposed the idea of a joint examining board for Ireland.
}

\section{6}

6 Old Palace Gard

London 16th Feb. 1872

My dear Thomson

We have just had a very small meeting of the [Royal] Commission today; but it was understood by those present that you will be welcome at your own time - i.e. during the meeting of the Med ${ }^{l}$ Council or immediately before. The $27^{\text {th }}$ will be a blank day no doubt being set apart for the Thanksgiving. Wednesday the $28^{\text {th }}$ would answer very well.

Mr. Sanderson has just come in after our meeting \& he seems anxious for full information respecting Nat. Philos. and Chem. Laboratories of Glasgow University. I told him that Sir W. Thomson might come again if wanted for that object - but that I feared Dr T. Anderson's state of health would be an obstacle to his appearing - but I concluded by telling him that no one could give such good information respecting 
Laboratories, Dissecting Rooms, Museums, Libraries \&c. \&c. than you - and, as what he chiefly wished for was plans of these several departments - that I would ask you to bring them up with you, or such copies as could be used by the Commission. I think he would wish them to be given in the printed minutes of the Commission.

I suppose that what the Commission would specially want from you would be information as to the applications of money in teaching science in the Univ ${ }^{y}-$ for Assistants, Apparatus, Collections \&c. \& what more may be wanted for effectually carrying on the work, the question of Assistant Professors in certain departments. Further development of influences \& usefulness of the University as a scientific organization - e.g. towards instruction of school Teachers, practically and solidly in Science \&c.

John [Millar Thomson] dined with us on Monday with Turner \& [ . . ] Brown[?]. He is strong and active. With kind regards from Mrs T

Yours always sincerely

W Sharpey

Dr Allen Thomson

87

Wrote 5th May [This is in Thomson's hand.]

Hampstead 30th April 1872

My dear Thomson

I have both your Letters. As regards Grant, I think the Commission would be glad to hear him if he has an inclination to come before them. He might give his opinion not only of the Glasgow Observatory \& its relation to Observatories generally - and on the question of establishing new Observatories for observing the physical phenomena of the Sun and other celestial bodies. He may perhaps also have views as to general scientific Administration in connection with the Government.

Let me know about his wishes \& I will look to the matter.

I am glad to get your proposals for a Conjoint Scheme. The difference from ours is in restricting the conjoint Exam ${ }^{n}$ to the subjects which now constitute the $2^{\mathrm{d}}$ or final Examination and leaving the $1^{\text {st }}$ Exam $^{\mathrm{n}}$ to be conducted singly by any of the present Licensing Bodies. I can see why the Corporations are averse to merging the whole of their Examinations into the Common one, and allowing an exception to Univ ${ }^{y}$ Graduates (as in our Scheme) and I suppose you will have to be contented with this in the mean time. Nevertheless it is "per tanto" a divergence from a concentrated examination, and to me appears a blemish. With that exception I think the proposed plan is excellent - and I venture to predict that after some experience the Corporations will find it more advantageous to combine all their work. Moreover I apprehend they will be disappointed if they expect that candidates who have passed the $1^{\text {st }}$ Examination in Scotland (unless University Undergraduates) will be admitted to qualify under the joint scheme in England without going through the whole of the prescribed examination -1 
It did not occur to me that there was much to amend in your Answers to the [Devonshire] Commission. But considerable license is allowed in correction - provided always that an answer shall not be so altered as to make the question inapplicable.

Yours always sincerely

W Sharpey

Dr Allen Thomson

\footnotetext{
${ }^{1}$ The GMC discussed plans for the creation of a conjoint examining board for Scotland at length in March 1872. See: Br. med. J., 1872, i: 261-6. There were problems in following the English model because of the different relations between the universities and medical corporations in Scotland.
}

\section{8}

May 251872

I have been for some good while back troubled with incapacity of my bladder to keep a reasonable quantity, \& consequently have frequent calls. This makes me anxious in travelling. I think you told me you had a contrivance which relieved you from all trouble. Will you kindly tell me what it is called - and where it may be got - also send a sketch of it \& tell me how to use it.

$\mathrm{M}$ [ary?]. so far as I know is still in Arbroath

W.S.

\section{9}

\section{Univ $^{y}$ College, London}

24th October 1872

My dear Thomson

Mr William Longman ${ }^{1}$ called here yesterday \& I met him today by appointment in Paternoster Row. He wished to speak of Quain's Anatomy. His firm have bought the Copy right of it and he wished to advise us as to a new Edition.

I told him that when Rich. Quain \& I agreed to edit the $5^{\text {th }}$ Edit. our bargain with the Publishers was $£ 10 . .10$ per sheet for new matter $£ 3.3$ for revision of old text. That when another (or a successive Editor) was wanted we were employed on the same terms as for the $5^{\text {th }}$ (so long as we continued to be Professors of Anatomy \& Physiology in the College[]. Quain withdrew \& Ellis took his place then I was left alone and an arrangement made with you \& Cleland.

I explained that you \& I had recommended a rearrangement of the subjects in a new Edition. One part to contain Histology \& the structural \& physiological anatomy of the viscera - the microscopic anatomy of the teeth - the organs of senses - and all development \&c. the other part to contain the bare descriptive anatomy with the descriptions abridged. That with your approval and by desire of Walton I had urged Dr Gowers ${ }^{2}$ to eliminate flaws [?] \& condense the Second part \& that he had been some 
time employed on it $-\&$ that whatever else was done I trusted he would receive suitable remuneration - this $\mathrm{Mr} \mathrm{L}$. promised - I then told him that my eyesight was so deteriorated (worse than when we parted) that I could scarcely work (in scientific reading or writing) at night - moreover that I could not examine objects critically with the microscope - and that I would not undertake what I had intended when we made our suggestions to Walton. Mr L. then asked me to recommend some one - but I decided first to communicate with you-indeed I told him you had the whole arrangement much better in your head than $I$ have $-\&$ that after hearing from you I would speak with him again.

He wishes a distinct proposal to be made to his firm - \& so far as I can see he will be quite ready to go on the same terms as Walton; but there is no time to lose - and even if done rather roughly - it would be well to have the book ready for next year's use. But who is to take my place? I dont like to press it on you as you would have enough to do independently. Could \& would Cleland do - A good part of the matter might stand \& additions \& corrections put in when wanted. Michael Foster might do what is required - but I dont know what he may have on hand. But do you give your thoughts to the question \& let me hear from you-especially put into writing your understanding as to the modifications in the new Edition.

I told Longman of the extra impression which Walton had run off (how many copies I could not say) \& of the fact that his editor owed us a payment on that account. The Longmans have merely bought the copyright as offered in the market \& know nothing of the extra impression, but $\mathrm{Mr} \mathrm{L}$. offered to make inquiry about it. I do not expect we shall ever get anything out of it.

It would be a great pity to let the book drop \& if we cannot undertake the new Edition of course the Longmans may supply some other people - this I should greatly regret - The Book would now have a better chance than before.

I claim no right to be employed - on the contrary I am unable to accept the offer, but I see that the Longmans would be very much guided by my advice \& I should be much guided by you.

Whatever else you write pray put a definite proposal on paper which I can extract \& submit to the new publishers.

John spent a Sunday afternoon with me the other day - he is well \& hopeful.

I think our new entries will be a trifle fewer this year - but the registration of the College of Surgeons places Univ ${ }^{y}$ College and Guys equal in new entries \& above the other schools - then we beat Guys in Second year men but they are higher in $3^{\mathrm{d}}$ and $4^{\text {th }}$ a good lot of $4^{\text {th }}$ year men with us did not think of registering.

With kind regards to Mrs Thomson. I have scarcely light to see

Your always most sincerely \& attached

W Sharpey

Dr Allen Thomson

M.D. FRS

\&c.

${ }^{1}$ William Longman (1813-77), partner in the publishing firm.

2 William Richard Gowers (1845-1915), Assistant Physician at University College Hospital. 


\section{0}

My dear Thomson

Nov 1873

I had occasion yesterday to confer with Sharpey and Burdon Sanderson on the subject of a proposal of a gentleman to endow the Chair of Physiology in University College with $£ 300$ a year. ${ }^{1}$

Sharpey took the opportunity of saying that his wish was to withdraw from his Chair at the end of the current session retaining the Directorship of the Museum which has a small salary attached to it. He said that his private means added to the salary of the Directorship would be enough to satisfy his wants. When Sanderson and I were alone he asked me if I knew enough of Sharpey's affairs to feel sure that he would really have a sufficiency to retire upon. My answer was that, I knew he had some savings that, his habits were not expensive and that, probably he had not overestimated his resources but that, I thought you might know more than I did of his private affairs and that I would write to you and inquire. Can you give me any information on this head? As a member of the College Council I can say that no Professor is more respected by them and that they would one and all be anxious to make the remainder of Sharpey's days easy but on the other hand I must acknowledge that the resources at our disposal and the precedent in relation to others would make it difficult to [sic] us to assign a pension to him. It would be a great relief to me and Sanderson, and I am sure to others also, to feel sure he did not need it but in case of uncertainty we should like to consider what it might be practicable to do for him.

As regards retirement I should not like for Sharpey's sake to dissuade him from taking a step which will be honourable to him. At the end of this Session he could withdraw with undimmed reputation; it would be a risk for him to hang on longer except as a means of introduction to a successor by giving a few lectures.

At your convenience will you give me a few lines. Sharpey is in fair health and spirits but his sight is very defective and I doubt if it is likely to mend.

You will be surprised to see we have moved into town. Various reasons have reconciled us to leaving Hampstead and we are very comfortable here.

My wife is pretty well and unites with me in kindest regards to you and Mrs Thomson.

Believe me

Yours most faithfully

John Storrar

Let Sharpey's intentions be a secret for the present.

${ }^{1}$ I.e., the bequest which led to the creation of the Jodrell Chair of Physiology at University College. 


\section{1}

University, Glasgow

11 th November 1873

My dear Dr. Quain,

I need not attempt to express the pleasure I received from the assurance conveyed by your letter of yesterday that the proposal to acknowledge our friends long and faithful services in the Cause of education and scientific progress by some substantial reward was likely to be well received in influential quarters.

Nor can I tell you how grateful I feel to you for your prompt exertions in the cause. I wish sincerely I could in any way assist; but I fear I have no influence, beyond the strong expression of the opinion of one who, having been on terms of the most intimate friendship with Sharpey for five and forty years is perhaps better acquainted with his deserts than any other person living. In our frequent and often prolonged intercourse through the whole of that period I have ever felt the influence of his elevated character and sound judgment in benefitting myself. I know this feeling to be shared by all those who have had the happiness of his friendship as well as by all his pupils - I know too the sacrifice he made in declining the Edinburgh Chair of Anatomy, in the possession of which he would have been wealthy beyond most scientific men, and from which he could now have retired upon more than a competency. But beyond all this all the world knows with what singular devotion, ability, judgment and entire negation of self Sharpey has spent the whole of his life in the pursuit and advancement not merely of his own special department but of a considerable range of sciences - His retiring disposition alone has prevented him from occupying more prominent positions; And I cannot but feel that while his present circumstances call urgently for something being done to smooth the course of his advanced years, the Government in giving him an ample pension would not only do an act of justice, certain to meet with universal approval, but $w^{d}$ also do itself honour in marking its appreciation of such faithful and able exertions and of so disinterested a life.

I need only add that I know that without provision from other sources than his own property it would be impossible for Sharpey to live at all comfortable after a retirement from his present office.

Earnestly hoping that you may be successful in your efforts,

I am ever sincerely yours

AT

[This is a heavily corrected draft of the letter.]

\section{2}

Wrote $25^{\text {th }}$ [This is in Thomson's hand.]

My dear Thomson

50 Torrington Square, Lond. 24th Feb. 1874

I have returned the specimens to Mr Longman, preferring $\mathrm{N}^{\circ} \cdot 2$.

I meant to have written yesterday, as in duty bound to my old and attached friend, to 
inform him that on Saturday I had a most kind letter from Lord Granville containing the most unlooked for intelligence that I had been assigned a pension of $£ 150$ on the Civil List. I suspect that you and Dr. Quain must have first moved in the matter. ${ }^{1}$

As it is this very welcome resource added to my stipend here (of $£ 100$ ) which I expect to retain on retiring, as I shall do from my Professorship at the end of this session - together with what I shall have in other ways, will put me quite at my ease.

I may tell you as my friend, and privately, that I have very nearly $£ 200$ a year from investments and hope to make it more by investing part of what is now at my Banker's - what [sic] ought to bring $£ 50$. Then my nephew $\mathbf{W}^{\mathrm{m}} \cdot \mathbf{H}^{\mathrm{n}}$. Colvill, who was educated \& brought up as well as set out at my charge - makes me a very liberal contribution of $£ 200$ a year.

This he could not afford to do were he to retire from the Service, which must some time come to pass - but even in that case I should, as you see, be very well off.

Parkes $^{2}$ was here examining for the Army on Saturday. He spoke favourably of John's progress towards recovery.

As to my eyesight, I am alternately despondent and hopeful. I gave along account of my state to Reid $^{3}$ - saying he might show it to you. He has written me his opinion which I regard as very important. This letter is written with my "operated eye" with the aid of glasses combining a cylindrical with a spherical curve.

Your acc of Mrs $\mathrm{W}^{\mathrm{m}} \mathbf{4}$ is very serious -

Your sincere friend

W Sharpey

${ }^{1}$ Sharpey's pension was announced in the Br. med. J., 1874, i: 354-5.

${ }^{2}$ Edward Alexander Parkes (1819-76), Professor of Hygiene at the Army Medical School, Netley.

${ }^{3}$ Presumably Thomas Reid (1830-1911), Surgeon at the Glasgow Eye Infirmary and Lecturer on Ophthalmic Medicine at the University of Glasgow.

${ }^{4}$ Presumably William Thomson's widow.

93

Mr dear Thomson

London, 16th $\operatorname{Dec}^{r} 1875$

A. B[uchanan].'s printed letter is indeed a (deplorable) curiosity. ${ }^{1}$ It is not merely dotage bursting out under temporary irritation - it shows an originally ill cultivated mind uncorrected by culture. It is monstrous to reflect that such a common kind of man should have been your Professor.

I will write to Foster about Balfour ${ }^{2}$ if you should still wish it - but I doubt if it would be advisable to look that way. The Physiology of [sic] must turn chiefly on function and its investigation through physics and chemistry - it must also take in histology - Now although I don't know that Balfour might not take ably and with relish to that side of the Subject, we know that his taste and favourite work have hitherto been in Morphology and Embryology - Your man must also be a good Human Anatomist as distinct from a Zootomist. 


\section{Letter 94}

Moreover, I scarcely think the plan would tempt Balfour - He has independent income of his own. As Fellow of Trinity I suppose he has $£ 350$ to $£ 400$ a year besides his rooms and dinners in Hall. Were I he I should keep myself free - to go to Naples, Norway or America when I liked.

I am glad that $\mathbf{M}^{c}$ Kendrick ${ }^{3}$ will apply - he is very much the man you want - up to modern physiology in a systematic way and long-versed in teaching Experimental Physiology - I should think he would be a great acquisition. I have heard of $\mathrm{Mr}$. Stirling ${ }^{4}$ most favourably - but beyond this I could form no opinion.

But then your supreme difficulty is what to do for the remainder of this session! You cannot leave the students utterly without instruction.

I hope you will not be worried with this troublesome business more than you can help. I fear Andrew [Buchanan] will make a fight about allowing a substitute to appear in his theatre - it might show that his difficulty of making himself heard is not solely due to acoustic defects in its construction.

As things are now - perhaps it is an advantage that he cannot be heard -

Yours most sincerely

W Sharpey

In haste

\footnotetext{
${ }^{1}$ In May 1875 Andrew Buchanan, Professor of the Institutes of Medicine at Glasgow, had published a sharp rejoinder to critical remarks about his teaching and standard of examining, made by members of the GMC. He appended a list of examination questions to his letter, challenging his detractors to submit answers to the Lancet. See the Lancet, 1875, i: 661. In December 1875 Buchanan announced his retirement from the chair.

${ }^{2}$ Francis Maitland Balfour (1851-82), embryologist. He was appointed lecturer on animal morphology at Cambridge in 1875 .

${ }^{3}$ John Grey McKendrick (1841-1925), lecturer on physiology in the Edinburgh extramural school. He succeeded Buchanan as Professor of Physiology at Glasgow in 1876.

${ }^{4}$ Presumably William Stirling (1851-1932), assistant to the Professors of Natural History and Physiology in Edinburgh. He became Professor of Physiology at Aberdeen in 1877 (see letter 99).
}

\section{4}

London 28. Dec 1875

My dear Thomson

I return by Book Packet [?] your two Sheets of Embryology. Do not bother yourself with my pencillings unless they consist of a positive mistake.

The book is promised in January - and considering the delay \& disappointments as well as the expedient had recourse to of separate previous issue of Vol 1 , it is absolutely indispensable that Messrs Longman should be able to keep promises. I beg therefore that you will not allow yourself to be distracted or diverted from the work by any other occupation except the delivery of your Lectures.

Foster happened to call on me shortly after I wrote to you last, I found he entirely agreed with me as to the unsuitability of the Gl. Chair for Balfour. He would take $\mathbf{M}^{\mathrm{c}}$ Kendrick. 
It would be most unfortunate if local influence should be allowed to prevail. ${ }^{1}$

Yours always sincerely

W Sharpey

nearly in the dark

Dr A Thomson

\footnotetext{
${ }^{1}$ McKendrick's claims to the Physiology Chair were challenged by a local candidate, Eben Watson (1824-86), Professor of Physiology at the Andersonian College (1850-76) and Surgeon at the Glasgow Royal Infirmary.
}

95

50 Torrington Square Monday mor ${ }^{\mathrm{n}}$

(21 ${ }^{\text {st }}$ Augt $^{\text {1 }}$ 1876)

My dear Thomson

I inclose a letter I have just received from Jenner. ${ }^{1}$

Sanderson has forwarded to me the joint representation ${ }^{2}$ desiring me to sign it \& send it to Hooker" (whose address is "care of F. Symonds Esq. Bridge Street Hereford[']).

Sanderson called on Paget on Saturday but found he had gone to Switzerland. If his name cannot be got I think (unless Acland joins) that it would be better for Hooker and Sanderson to write to Cross ${ }^{4}$ separately, especially as I doubt whether my name should be added (seeing that I have virtually written to Mr. Cross separately[)]. I have indeed signed the paper but I think that both Sanderson \& you will rather approve of its not appearing \& I have suggested to Sanderson to write out a fresh copy for Hooker's name should it still be thought advisable to send a joint recommendation.

I have returned the paper to Sanderson for the reason mentioned and also because if he wants his own signature -

Hoping I may see you tomorrow

Yours always

W Sharpey

Dr Thomson FRS

P.S. I have told Sanderson of your movements - and I shall be all day either here or at the College.

WS.

\footnotetext{
${ }^{1}$ William Jenner (1815-98), Physician-in-Ordinary to the Queen.

2 See letter 98.

${ }^{3}$ Presumably the botanist Joseph Dalton Hooker (1817-1911).

${ }^{4}$ Richard Assherton Cross (1823-1914) Home Secretary in Disraeli's government from 1874 to 1880 . The Glasgow physiology chair was in the gift of the Crown.
} 
96

Balmoral Castle

August $19^{\text {th }}$

1876

My dear Sharpey

As I shall I hope be away from Balmoral before Mr. Cross arrives (i.e. late in Sep ${ }^{t}$ I am told) I thought it better to send your letter to him at once - explaining to him the high value to be set on your Testimony - and I trust Dr. McKendrick may obtain the post - I have said \& done what I think best calculated to aid him.

Yours always very $\operatorname{Sinc}^{\mathrm{y}}$

W. Jenner

97

Wrote in March \& on $15^{\text {th }}$ April [This is in Thomson's hand.] London $17^{\text {th }}$ Feb. 1877

My dear Thomson

I had the [Glasgow] "Herald" this morning, with the beginning and end of your Lecture. ${ }^{1}$ I have no doubt your exposition of the mode of development \& its relation to the structure in animals must have been lucid and instructive. Your conclusions as to the dependence of mental manifestations on the cerebral organization are doubtless incontrovertible if your Darwinism (gently hinted) may be right, but you dared not have said as much when you suceeded Alison in Edinburgh \& if you had said as much before, the municipal Patrons (who would have refused Agassiz $^{2}$ for claiming more parents for the human race than Adam \& Eve) would never have promoted you! One is glad to find so liberal an Audience \& enlightened a Chairman as you enjoyed in Glasgow.

Now for myself. The first trials of my eye after operation were very promising - but a film soon occupied the visual opening - whether by deposit on the post ${ }^{r}$ lens capsule or independent of it I cannot tell. The appearance of the opening seen by me by aid of a pinhole - you may guess from the rude sketch I inclose viz. A. [see figure 8] The film persisting and rather getting worse, Streatfield with Couper's ${ }^{3}$ approval and assistance endeavoured to split it up with a needle. They had hoped it would spring open to the needle-cut. But it was tough and unmanageable and all that could be effected was to peel it away to the temporal side - about half way across - leaving one half floating in the aqueous humour with a thick border running vertically \& leaving about half the area clear to the nasal side. The membrane quivers with the movements of the eyeball but is still fixed somewhere on the temporal side.

The natural pupil was occupied with a dense looking brown mass - which is now half turned away. The sketches are placed as they appear to my vision by homocentric light - but as you know they are inverted and you must turn them to get the actual position. 


\section{Letter 97}

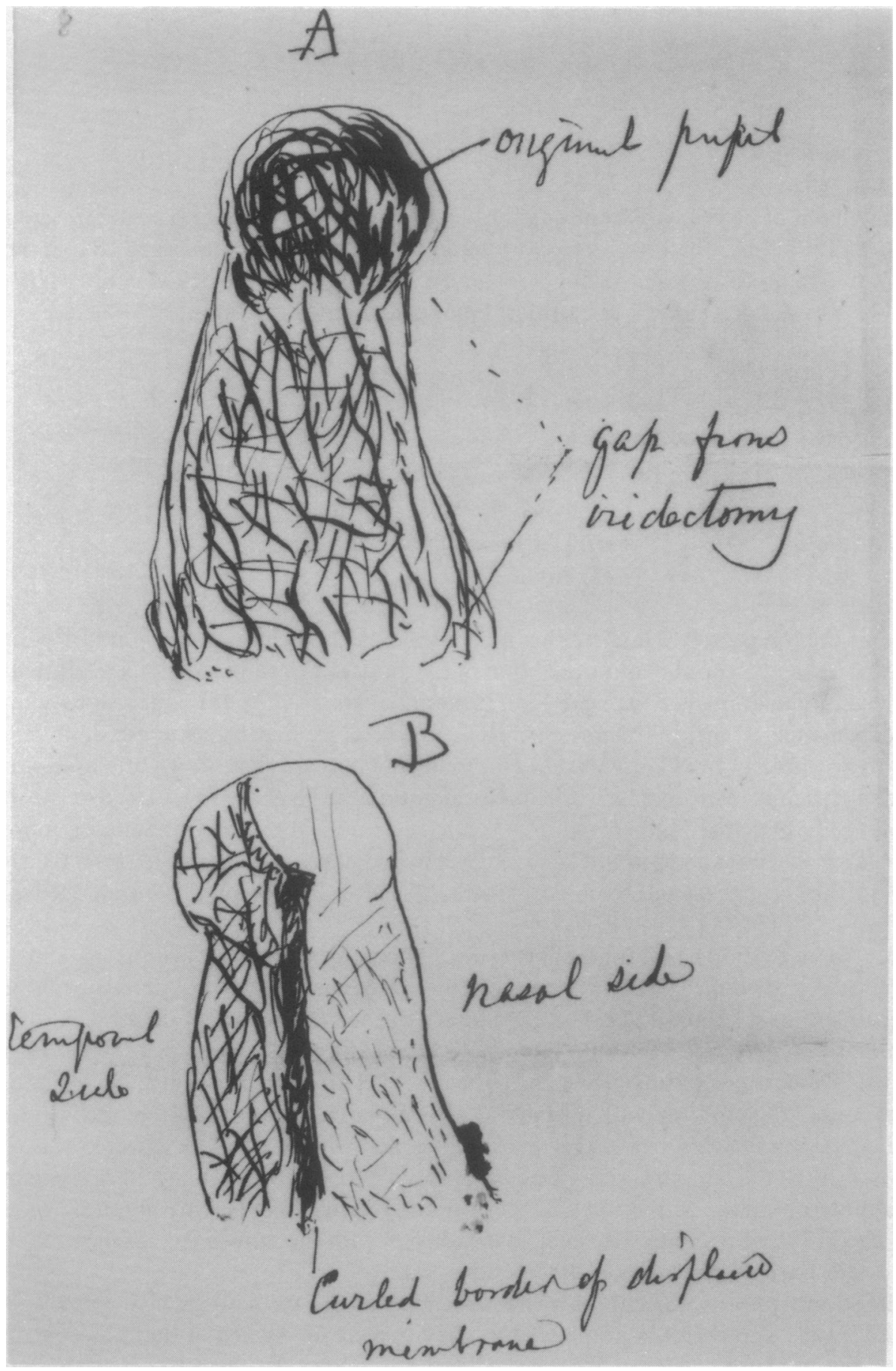

Figure 8 . 


\section{Letter 98}

Meanwhile I have now had spectacles for a week, made under J. Couper's direction - with a cylindrical error of $15 /$ inches radius - The distance glasses have hitherto answered well, but I am not satisfied with the near ones - or rather I ought to say that the obstruction in the eye tells more against "reading vision."

It is just possible that the offending membrane may yet shrink up - or become wasted, but I have no great hope of this, and I am contented to go on in the mean time in thankfulness especially as I can now walk the streets without fear.

Pray ask Reid kindly to say what he thinks[.] I hope $\mathbf{M}^{r}$ Macilwain's operation is now showing some result.

$\mathbf{M}^{r s}$ Sibson called two days ago to consult about the best depositing for her late husband's ${ }^{4}$ MSS, Drawings \&c. - and she brought with her a framed print of your Father which I had given to Sibson some time ago. She is now giving up the house in Brook Street \& has no space in the country (where she will now live) for hanging pictures - so she thought it best to return the one in question. Do you know any one who would like to have it? Had I not been writing to you I should have asked John - whether $\mathbf{M}^{\text {rs }}$ Aiken would care for it - but perhaps you may suggest a suitable bestowal of it.

John kindly assented to be one of my Trustees \& I have accordingly made a new Will and named Marshall \& John as Trustees.

I have heard from $\mathbf{W}^{m}$ Henry [Colvill] - first from Constantinople \& this morning from Cairo. He has got the Sanitary Commission at Constantinople to recommend two measures proposed by him in reference to quarantine and plague - I dont suppose he will do anything in Egypt which he visits merely as on the route to Bombay, whence he will travel by Steamer to Busrah [sic] \& Bagdad.

With kind regards to $M^{r s}$ T.

Yours always sincere friend

W Sharpey

$\mathrm{D}^{r}$ A. Thomson FRS

\footnotetext{
1 Thomson had given the last of a series of lectures on 'The evolution of the brain' at the City Hall, Glasgow. See the Glasgow Herald, 16 February 1877.

2 Jean Louis Rodolphe Agassiz (1807-73), Swiss naturalist who strongly opposed the Darwinian theory.

${ }^{3}$ John Fremlyn Streatfield (1828-86), and John Couper (1835-1918), Surgeons at the Royal London Ophthalmic Hospital. These remarks refer to an eye operation Sharpey had undergone in October 1876

${ }_{4}^{4}$ I.e., Francis Sibson (1814-76), who had studied medicine at Edinburgh before becoming Physician to St Mary's Hospital, London.
}

\section{8}

London 50 Torrington Square

$3^{d} \operatorname{Sep}^{t} 1877$

My dear Thomson

The case is not an easy one to deal with. ${ }^{1}$ When the Physiology Chair was in question, the competitor of $\mathbf{M}^{\mathrm{c}}$ Kendrick had brought to bear very strong local influence - and this publicly and avowedly in his favour, as a Glasgow Man - and 
there was no difficulty in joining in a remonstrance against the possible sacrifice of the interest of the University and the scientific reputation of the Chair to local clamour and political pressure - but in the present case any representation to $\mathrm{Mr}$. Cross could scarcely refer openly to Court influence - as opposed to scientific merit. No doubt a strong expression in favour of bestowing the place on a Candidate who would maintain \& enhance the reputation of the institution - might properly be made - but as there are two candidates who fulfil that condition - the interposition proposed - would simply be a warning against the third; and then his tried success as a teacher who has worked on in Glasgow in view of getting into the Univ ${ }^{y}$ might be urged in his favour. ${ }^{2}$ I confess I am at a loss what to advise - I have seen Sanderson this morning - he feels that his position scarcely warrants him in taking a prominent part as he did when physiology was the question - but I doubt not he would join in any measure which should be supported by any considerable number of scientific men - This however can scarcely come about. We both think you might write to Huxley and to Owen and learn what they could or would do - Also Turner ${ }^{3} \&$ Struthers ${ }^{4}$ might aid - tho' perhaps Turner might not care to see a powerful rival in Glasgow. Why not put the case before your Chancellor Sir. W. Maxwell? ${ }^{5}$ If you would move in it the Gov ${ }^{t}$ would be strengthened in resisting Court influence - supposing Mr. Cross wished to resist it. The chief use of a round-robin would be to create an outside cry (in the Medical Profession) against throwing away the opportunities of promoting science.

I called at Busk's house \& find he is at Ambleside - his address is "Hill-top" or "Top-Hill" I forget which, Ambleside.

I wrote some time ago to Jenner in favour of Stirling for Aberdeen \& got a most friendly answer, but Jenner could only communicate wth Mr. Cross if they should meet - for when he wrote to him about the Edin. Clin. Surg ${ }^{y} \mathrm{Chair}^{6}$ he was told by Mr. C's Secretary substantially but in civil terms that he had better wait till his opinion was asked.

You will gather from this disjointed note that I feel quite at Sea in the matter.

Suppose you begin by drawing up a short address to Mr. Cross \& send it for consideration to such people as you would like to join in it - say Owen, Huxley, Busk[,] Sanderson[,] Flower[,] $]^{7}$ Turner[,] Struthers \& me. I cannot find whether Huxley is in London. But write to the usual address (to be forwarded).

Yours sincerely

W Sharpey

Dr Allen Thomson

\footnotetext{
1 Thomson vacated the Anatomy Chair at Glasgow in 1877; he was succeeded by his former assistant John Cleland.

2 This third candidate may have been George Buchanan, a lecturer on anatomy at the Andersonian College. On the second "desirable" candidate see the next letter.

${ }^{3}$ William Turner (1832-1916), Professor of Anatomy in Edinburgh.

4 John Struthers (1823-99), Professor of Anatomy in Aberdeen.

${ }^{5}$ William Stirling-Maxwell (1818-78) landed magnate and historian. He had been Chancellor of Glasgow University since 1876.

${ }^{6}$ The Edinburgh Clinical Surgical Chair became vacant in 1877 upon Lister's transfer to King's College, London.

${ }^{7}$ William Henry Flower (1831-1899), Hunterian Professor of Comparative Anatomy at the Royal College of Surgeons of London.
} 


\section{Torrington Square London WC $22^{\mathrm{d}}$ Sep $^{\mathrm{t}} 1877$}

\section{My dear Thomson}

I have within the last two or three days been trying a little practical work in the College - looking over my old preparations of the bitch's Uterus.

I was seized yesterday with my vertigo - after being free from it for nearly four months - but I hope to be right again - and should be glad to have a specimen of the unimpregnated uterus of the bitch also of an impregnated one in which the foetal compartments are about the size of a walnut or a little less. It occurs to me that you might fall on something of the kind in rummaging among your old traps during the process of their removal to the Univ ${ }^{y}$ Museum - and I therefore ask you kindly to help me.

I saw Stirling on Wednesday - on his way to Paris to look after teaching and working appliances suited to his new position [as Professor of Physiology at Aberdeen] - his attainment of which I need hardly say has been a great satisfaction to friends here - not only on his account but as some token that Government patronage in the Scottish Universities will be thoughtfully and judiciously bestowed. He tells me that your succesion will be between Cleland and Macalister ${ }^{1}$ - and I hope he may be right. It would help to a satisfactory conclusion if some preference were come to between the two desirable candidates. Mr. Cross I see by the papers is at Balmoral and Jenner is there - Should Jenner be consulted I have no doubt he will give good advice. On all hands, that is, among all people who set the interests of Science above personal favour - it is anxiously hoped that so important a Chair will be worthily filled.

The St. George's people have I suspect made a mistake. Wanklyn ${ }^{2}$ is no doubt a clever man and of considerable scientific reputation - but he does not get on with brother chemists. John [Millar Thomson] would have been a much better man for them.

Hoping to see you in no long time

Yours always as before

W Sharpey

Dr Allen Thomson

\footnotetext{
${ }^{1}$ Presumably Alexander Macalister (1844-1919), Professor of Comparative Anatomy and Zoology at the University of Dublin.

2 James Alfred Wanklyn (1834-1906), Lecturer in Chemistry and Physics at St George's Hospital, London.
} 